2015-02-14

Bedform contributions to cross-shore sediment transport on a dissipative beach

\author{
Miles, Jonathon
}

http://hdl.handle.net/10026.1/5428

10.1016/j.coastaleng.2015.01.007

Coastal Engineering

Elsevier BV

All content in PEARL is protected by copyright law. Author manuscripts are made available in accordance with publisher policies. Please cite only the published version using the details provided on the item record or document. In the absence of an open licence (e.g. Creative Commons), permissions for further reuse of content should be sought from the publisher or author. 


\title{
Bedform contributions to cross-shore sediment transport on a dissipative beach
}

\author{
Jon Miles $^{* \mathrm{a}}$ and Antony Thorpe ${ }^{\mathrm{a}}$ \\ ${ }^{a}$ School of Marine Science and Engineering, Plymouth University, Plymouth, PLA 8AA, UK. \\ *Corresponding author: Tel.: +44 1752 584737; Fax: +44 1752586101. \\ E-Mail address: jrmiles@ plymouth.ac.uk. \\ Accepted for Coastal Engineering 28 th Jan 2015. Doi: 10.1016/j.coastaleng.2015.01.007
}

\begin{abstract}
Field measurements of hydrodynamics, suspended sediment transport rates and bedform sediment transport rates were made in the intertidal section of a dissipative sandy beach $\left(\mathrm{D}_{50}=0.26 \mathrm{~mm}\right.$, slope $\left.=1 / 80\right)$ at Perranporth $(\mathrm{UK})$. Pressure Transducers, Acoustic Doppler Velocimeters, Optical Backscatter Sensors and an acoustic Sand Ripple Profiler were deployed for 12 tides, measuring in a range of wave heights from 0.5 to $2.2 \mathrm{~m}$, water depths from 1 to $6 \mathrm{~m}$, and in current strengths up to $0.4 \mathrm{~m} / \mathrm{s}$. Data were analysed in terms of the distance to shore $(\mathrm{x})$ normalised by the surf zone width $\left(\mathrm{x}_{\mathrm{s}}\right)$, and spanned the region $0.4<$ $\mathrm{x} / \mathrm{x}_{\mathrm{s}}<3$. Bedforms heights up to $30 \mathrm{~cm}$ and wavelengths 0.5 to $2.7 \mathrm{~m}$ were recorded. Maximum wavelengths were observed just shoreward of the breakpoint. Bedforms were classified as sub-orbital, vortex ripples. Bedform migration was mostly onshore directed, and correlated with positive (onshore) wave skewness. Migration rates increased through the shoaling zone to a maximum of $1.5 \mathrm{~cm} / \mathrm{min}$ just shoreward of the breakpoint $\left(\mathrm{x} / \mathrm{x}_{\mathrm{s}}=0.8\right)$. The bedform component of sediment transport was generally onshore directed, and maximum just shoreward of the breakpoint $(0.021 \mathrm{~kg} / \mathrm{m} / \mathrm{s})$. Point measurements showed that the cross-shore suspended sediment transport $25 \mathrm{~cm}$ above the bed was dominated by the mean component, with an offshore directed maximum at $\mathrm{x} / \mathrm{x}_{\mathrm{s}}=0.5$. Contributions to onshore transport were only made by the incident wave (gravity band) component. The total depth integrated suspended sediment transport was offshore directed and maximum in the mid surf zone $(-0.16$ $\mathrm{kg} / \mathrm{m} / \mathrm{s})$. The depth integrated suspended sediment transport dominated over the bedform sediment transport in the inner to mid surf zone $\left(\mathrm{x} / \mathrm{x}_{\mathrm{s}}<0.5\right)$ and in the outer shoaling zone $\left(\mathrm{x} / \mathrm{x}_{\mathrm{s}}>1.5\right)$. The fractional contribution of the shoreward directed bedform transport to the total absolute transport was up to $100 \%$, and occurred broadly in the region of the breakpoint $\left(0.5<\mathrm{x} / \mathrm{x}_{\mathrm{s}}<1.5\right)$. However, spatial averaging in the cross-shore indicated that a more realistic bedform contribution was up to $15 \%$ of the transport, with a maximum at $\mathrm{x} / \mathrm{x}_{\mathrm{s}}=0.9$. Results from this dissipative beach experiment generally agree with previous findings on intermediate beaches, steep beaches, and offshore sandbars.
\end{abstract}

Keywords: surf zone processes, dissipative beach; cross-shore sediment transport; bedform migration; suspended sediment transport; field measurements 


\section{Introduction}

Bedforms are ubiquitous features of sandy nearshore environments, and are prevalent in the shoaling and surf zones. They play an important role in controlling bed roughness (Feddersen et al., 2003; Gallagher, 2003), and their migration makes a contribution to the overall sediment transport budget (Huntley et al., 1991). Bedforms have been shown to contribute to the total sediment transport budget on intermediate beaches (Masselink et al., 2007) and reflective beaches (Aagard et al., 2012). This paper focusses on the contribution of bedforms to the total sediment transport budget on a dissipative beach, and examines the cross-shore distribution of this transport.

In relatively deep water seaward of the surf zone, ripple migration has been shown to be a major component in the overall sediment transport budget. On a sandy ridge in $11 \mathrm{~m}$ water depth, Traykovski et al. (1999) measured wave ripples with wavelengths up to $1 \mathrm{~m}$, and amplitude $15 \mathrm{~cm}$ moving onshore at rates of up to $80 \mathrm{~cm} /$ day. The suspended transport was a factor of 20 less than the transport accounted for by the bedforms in the deep water. On a sand bar in roughly $20 \mathrm{~m}$ water depth in the North Sea, Williams and Rose (2001) measured ripples of length 0.44 to $1 \mathrm{~m}$, migrating at up to $1.18 \mathrm{~mm} / \mathrm{s}$. The bedform transport was dominant over the suspended transport, with volumetric transport rates up to $8.37 \times 10^{-5} \mathrm{~m}^{2} / \mathrm{s}$ while suspended sediment transport rates reached $3.98 \times 10^{-5} \mathrm{~m}^{2} / \mathrm{s}$.

Approaching the surf zone from offshore, Clifton et al. (1971) observed that the wave ripples which typically form in deeper water change to become megaripple features in the surf zone, with larger wavelengths and heights. The shoaling zone and surf zone megaripple heights are typically 0.1 to $0.5 \mathrm{~m}$, and lengths are typically $0.5 \mathrm{~m}$ to $5 \mathrm{~m}$ (Gallagher et al., 1998b; Gallagher, 2003). Field measurements show that the bed roughness associated with these features is largest at moderate mobility numbers (Gallagher et al., 2003). Megaripples are reported as three-dimensional, and although they may take on a regular alongshore structure, they may also develop as hummocks and holes in a less regular distribution (Gallagher, 2003). The direction of megaripple advance is generally shoreward (e.g. Ngasuru and Hay, 2004), and migration rate has been shown to depend on the incident wave skewness (Crawford and Hay, 2001; Gallagher et al., 2003), and the mobility number (Vincent et al., 1993; Traykovski et al., 1999).

Masselink et al. (2007) investigated variations in ripple migration rates on a coarse grained intermediate sandy beach $\left(\mathrm{D}_{50}=0.7 \mathrm{~mm}\right)$ at Sennen (UK). Ripple heights of $0.05 \mathrm{~m}$ and lengths of $0.35 \mathrm{~m}$ were recorded, and migration rates were approximately $0.1 \mathrm{~cm} / \mathrm{min}$ onshore in the shoaling zone. In low-wave conditions, bedform transport rates (wave ripples) were of the same order of magnitude as suspended load rates. In high energy conditions however, the bedform transport was an order of magnitude lower. In the outer surf, Masselink et al. (2007)

measured onshore directed ripple migration rates of $2 \mathrm{~cm} / \mathrm{min}$. Here, bedform transport rates were an order of magnitude smaller than the suspended transport. No bedform transport took place in the inner surf. 
On a steep beach at Pearl Beach, NSW Australia, (gradient $=1 / 10 ; \mathrm{D}_{50}=0.25$ to 0.45 $\mathrm{mm}$ ), Aagard et al. (2013) found bedform transport in $2 \mathrm{~m}$ water depth was onshore directed in 'post-storm' conditions $\left(\mathrm{H}_{\mathrm{s}} \sim 0.5 \mathrm{~m}\right)$, but offshore directed in the 'storm' conditions $\left(\mathrm{H}_{\mathrm{s}} \sim\right.$ $1 \mathrm{~m})$. In the post-storm conditions, the net suspended sediment transport was offshore directed and approximately an order of magnitude larger than the net bedload transport. The data for the storm conditions showed variable dominance, due to variability in the suspended sediment transport values.

Suspended sediment transport rates are often described in terms of their cross-shore position relative to the surf zone (e.g. Marino-Tapia et al., 2007a). Observations of onshore directed sediment transport in shoaling waves outside the surf zone (e.g. Hanes and Huntley, 1986), offshore directed sediment transport by undertow inside the surf zone (e.g. Osborne and Greenwood, 1992; Russell, 1993), and onshore directed sediment transport in the swash zone (e.g. Masselink and Russell, 2006; Miles et al., 2006) have led to 'shape functions' that parameterize cross-shore transport rates as a function of distance from the shore, normalized by surf zone width (Russell and Huntley, 1999; Tinker et al., 2009). This approach has given some success in replicating morphological features such as surf zone bar crest position (Marino Tapia et al., 2007b). These studies have not yet been able to incorporate bedform transport rates, but the cross-shore distribution approach offers a useful framework within which to consider the contribution of bedforms.

The general understanding of the bedform contribution to sediment transport is that in deep water, the bedform component is onshore, and large compared to the suspended component. Towards the shore (through the shoaling and surf zones), the suspended transport becomes progressively more important. This observation is based on data from offshore sandbars (e.g. Traykovski et al., 1999), macrotidal coarse grained steep beaches (e.g. Masselink et al., 2007), and micro tidal fine grained intermediate beaches (e.g. Ngasuru and Hay, 2004). In this paper, analysis of the cross-shore distribution of bedform sizes, migration rates and contribution to sediment transport are presented from a dissipative beach. The data extends from relatively deep water $(\sim 6 \mathrm{~m})$ through shoaling wave conditions with skewed waves, into the surf zone where incident waves and offshore directed undertow contribute to controlling the sediment dynamics.

\section{Field Measurements}

Field measurements were made at Perranporth (Cornwall, UK), where a macrotidal, dissipative sandy beach faces WNW into the Atlantic Ocean (Fig. 1) (Miles et al., 2014a). A rig of instruments was deployed near the low water mark, close to LW springs. The wave climate at the site gives a mean offshore wave height of $1.6 \mathrm{~m}$ (Davidson et al., 1997), and the mean tidal range is $6.1 \mathrm{~m}$. 


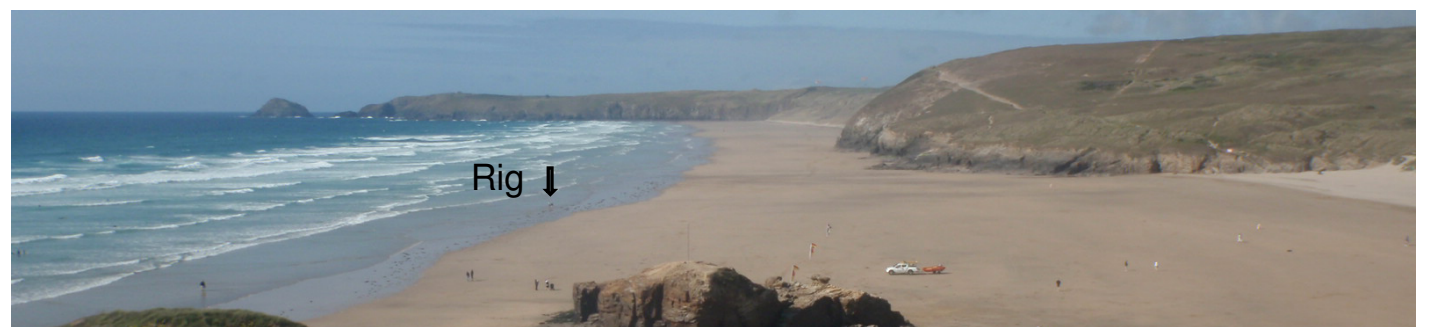

Fig. 1. General view of Perranporth beach during the experiments in May 2011, showing the rig position at approximately LW springs.

Data is presented here spanning twelve separate high tides, from May 2011 (6 tides) and October 2011 (6 tides). The beach profile was reasonably linear, with an average slope of 1/80 (Fig. 2). The tide flooded and ebbed over the instrument rig, and measurements were therefore possible in water depths up to $6 \mathrm{~m}$, and at different cross-shore locations relative to the surf zone. Sediments sampled at the rig location were medium sand $\left(D_{50}=0.28 \mathrm{~mm}\right)$.

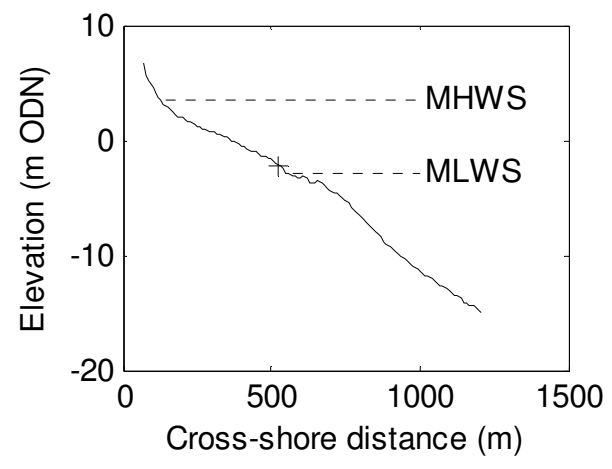

Fig. 2. Beach profile at the site, showing the rig position (+), Mean High Water Springs (MHWS) and Mean Low Water Springs (MLWS). ODN refers to Ordnance Datum Newlyn (approximate UK mean sea level datum).

The general layout of the instrument rig is shown in Fig. 3. A Pressure Transducer (PT) was mounted at bed level to measure water depths and wave heights. Flow velocities were measured using an Acoustic Doppler Velocimeter (ADV). The sensing volume was $25 \mathrm{~cm}$ above the bed. The sensor was carefully aligned to measure on-offshore velocities. Two Optical Backscatter Sensors (OBSs) were used to measure suspended sediment concentrations. These were deployed at 5 and $15 \mathrm{~cm}$ for the first six tides and at 25 and $40 \mathrm{~cm}$ above the bed for the second six tides. Bedform elevation measurements were made using a Sand Ripple Profiler (SRP). This was positioned $90 \mathrm{~cm}$ above the bed, taking a shore-normal line scan of length $2 \mathrm{~m}$, once per minute. SRP data was processed to give regular horizontal (on-offshore) resolution of $1 \mathrm{~cm}$ over the scan. 


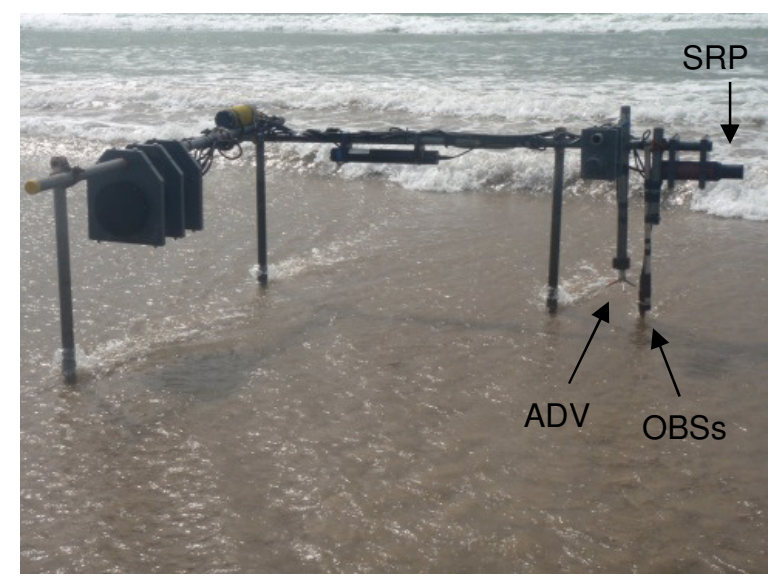

Fig. 3. Instrumented rig in-situ, showing the Sand Ripple Profiler (SRP), Acoustic Doppler Velocimeter (ADV) and Optical Backscatter Sensors (OBSs). The cylinders to the side contain the batteries, conditioning electronics and data loggers.

The ADV, OBS and PT data were recorded continuously at $16 \mathrm{~Hz}$ (first six tides) and $8 \mathrm{~Hz}$ (second six tides). The data were separated into sequential 10-minute long sections (runs), and these were analysed to give hydrodynamic and sediment dynamic parameters. Corresponding bedform parameters were calculated from the SRP data. Data is presented here from when the water depth was greater than $0.9 \mathrm{~m}$, when all instruments were submerged and functioning simultaneously.

\section{Hydrodynamics}

Hydrodynamic conditions for each of the tides recorded at the rig are shown in Fig. 4. Dry periods at low water between experiments have been removed. Water depths when all instruments were submerged and functioning were in the range 0.9 to $6 \mathrm{~m}$. Wave heights $\left(\mathrm{H}_{\mathrm{s}}\right)$ were calculated using a standard $\mathrm{H}_{1 / 3}$ zero up-crossing method, having first corrected for depth attenuation. $\mathrm{H}_{\mathrm{s}}$ was in the range 0.48 to $2.19 \mathrm{~m}$. Wave period, calculated as $\mathrm{T}_{1 / 3}$, showed that the site experienced mostly swell waves $\left(\mathrm{T}_{1 / 3}=10\right.$ to $\left.11 \mathrm{~s}\right)$, although data were also collected for $\mathrm{T}_{1 / 3}=7$ to $8 \mathrm{~s}$.

The instruments in this experiment measured processes at different cross-shore locations in the surf zone, due to the large tidal range at the site. A normalised expression for the crossshore distance from the shore to the instruments $(\mathrm{x})$ in relation to the surf zone width $\left(\mathrm{x}_{\mathrm{s}}\right)$ was identified from the water depth $(\mathrm{h})$ and the break point water depth $\left(\mathrm{h}_{\mathrm{b}}\right)$ by assuming that the profile of the beach was reasonably linear:

$$
\frac{x}{x_{s}}=\frac{h}{h_{b}}
$$

The breakpoint water depth $\left(h_{b}\right)$ was predicted for each tide using $h_{b}=H_{b} / \gamma$, where $H_{b}$ is the breakpoint wave height, and $\gamma$ is the breaker coefficient. To calculate $\mathrm{H}_{\mathrm{b}}$ for each tide, the 
wave height measurements at high tide (6 m depth) were assumed to represent 'offshore' conditions $\left(\mathrm{H}_{\infty}\right)$. The breakpoint wave height was calculated using the Komar and Gaughan (1972) equation:

$$
H_{b}=0.39 g^{1 / 5}\left(T H_{\infty}^{2}\right)^{2 / 5}
$$

A value of $\gamma=0.5$ at the breakpoint corresponded with the maximum wave heights measured (Fig. 5). A comparison with the incident wave cross-shore velocity variance also indicated a peak at $\gamma=0.5$. This analysis indicated that the instruments are typically measuring in the surf zone at the start and end of each tide, and measured a distance of up to 2-3 times the surf zone width seaward of the shoreline when waves were small.
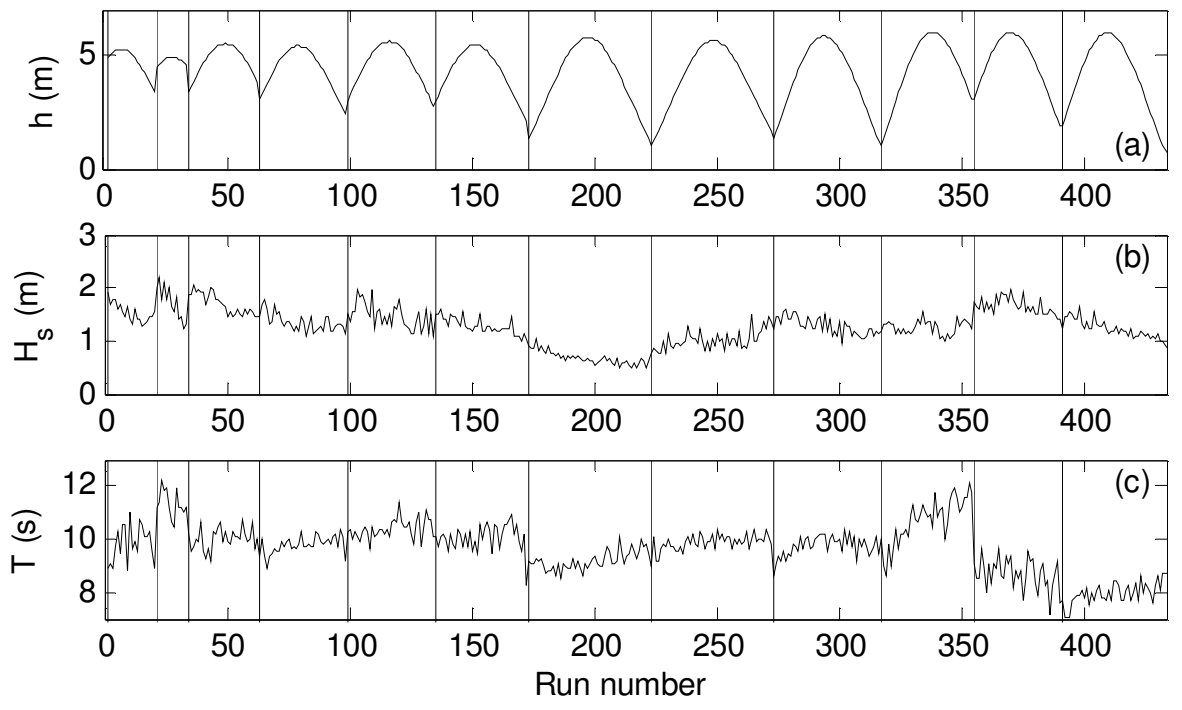

Fig. 4. Hydrodynamic parameters showing (a) water depth (h); (b) wave height $\left(\mathrm{H}_{\mathrm{s}}\right)$; and (c) wave period (T) for each 10-minute run analysed. Vertical lines separate different tides of data.

The instruments in this experiment measured processes at different cross-shore locations in the surf zone, due to the large tidal range at the site. A normalised expression for the crossshore distance from the shore to the instruments $(\mathrm{x})$ in relation to the surf zone width $\left(\mathrm{x}_{\mathrm{s}}\right)$ was identified from the water depth $(\mathrm{h})$ and the break point water depth $\left(\mathrm{h}_{\mathrm{b}}\right)$ by assuming that the profile of the beach was reasonably linear:

$$
\frac{x}{x_{s}}=\frac{h}{h_{b}}
$$

The breakpoint water depth $\left(h_{b}\right)$ was predicted for each tide using $h_{b}=H_{b} / \gamma$, where $H_{b}$ is the breakpoint wave height, and $\gamma$ is the breaker coefficient. To calculate $\mathrm{H}_{\mathrm{b}}$ for each tide, the wave height measurements at high tide (6 m depth) were assumed to represent 'offshore' conditions $\left(\mathrm{H}_{\infty}\right)$. The breakpoint wave height was calculated using the Komar and Gaughan (1972) equation: 


$$
H_{b}=0.39 g^{1 / 5}\left(T H_{\infty}^{2}\right)^{2 / 5}
$$

A value of $\gamma=0.5$ at the breakpoint corresponded with the maximum wave heights measured (Fig. 5). A comparison with the incident wave cross-shore velocity variance also indicated a peak at $\gamma=0.5$. This analysis indicated that the instruments are typically measuring in the surf zone at the start and end of each tide, and measured a distance of up to 2-3 times the surf zone width seaward of the shoreline when waves were small.
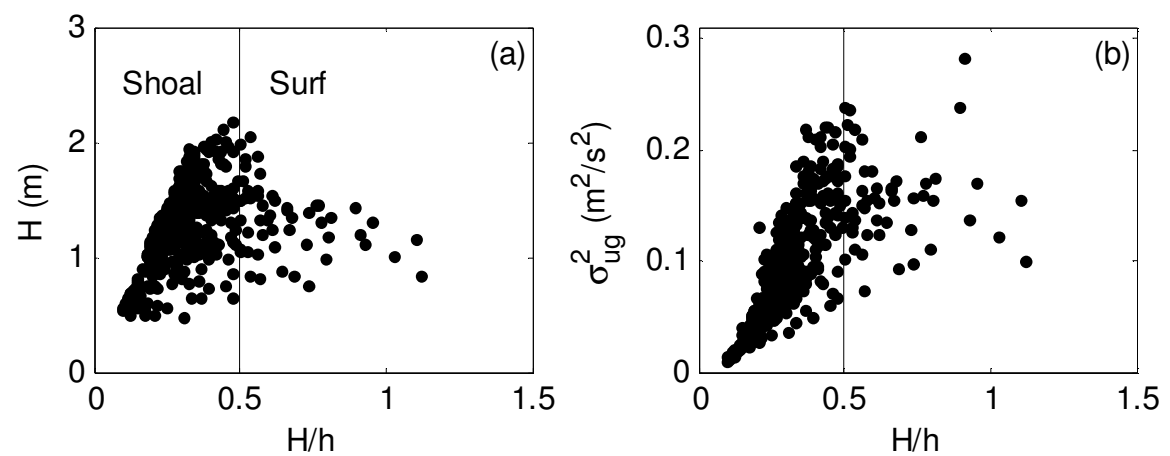

Fig. 5. Values of (a) wave height $(\mathrm{H})$; and (b) incident wave band cross-shore velocity variance $\left(\sigma_{\text {ug }}^{2}\right)$, varying with $H / h$. The peaks at $H / h=0.5$ indicate the approximate position of the breakpoint.

The cross-shore position indicated by $\mathrm{x} / \mathrm{x}_{\mathrm{s}}$ was compared to the mean flow measurements (Fig. 6). At the height above the bed measured by the ADVs, the mean cross-shore velocity is expected to be weak outside the surf zone, but stronger and directed offshore inside the surf zone due to undertow. Mean cross-shore velocities were either close to zero at high tide, or offshore-directed in shallower water, reaching a maximum strength of $-0.34 \mathrm{~m} / \mathrm{s}$. The values of $\mathrm{x} / \mathrm{x}_{\mathrm{s}}<1$ correspond closely with the times when the cross-shore flows were measured as offshore-directed, and the technique is therefore taken as a reasonable guide for identifying when the rig was in the surf zone, and quantifying the non-dimensional cross-shore location of the rig in terms of $\mathrm{x} / \mathrm{x}_{\mathrm{s}}$. The mean longshore currents (up to $0.2 \mathrm{~m} / \mathrm{s}$ ) were tidally modulated. They were close to zero outside the surf zone at high tide, were directed to the North on the flood tide, and to the South on the ebb tide.

To put the sediment dynamic observations into context, a summary of key hydrodynamic observations is presented. The cross-shore distribution of orbital velocity, mean current, wave skewness and orbital diameter are shown in Fig. 7. Orbital velocity was calculated as $u_{m}=$ $2 \sqrt{ } \sigma_{u}^{2}$ (where $\sigma_{u}^{2}$ is the total cross-shore velocity variance) following Masselink et al. (2007). Orbital velocities increased shoreward. Larger orbital velocities were observed on tides with larger offshore wave height. 

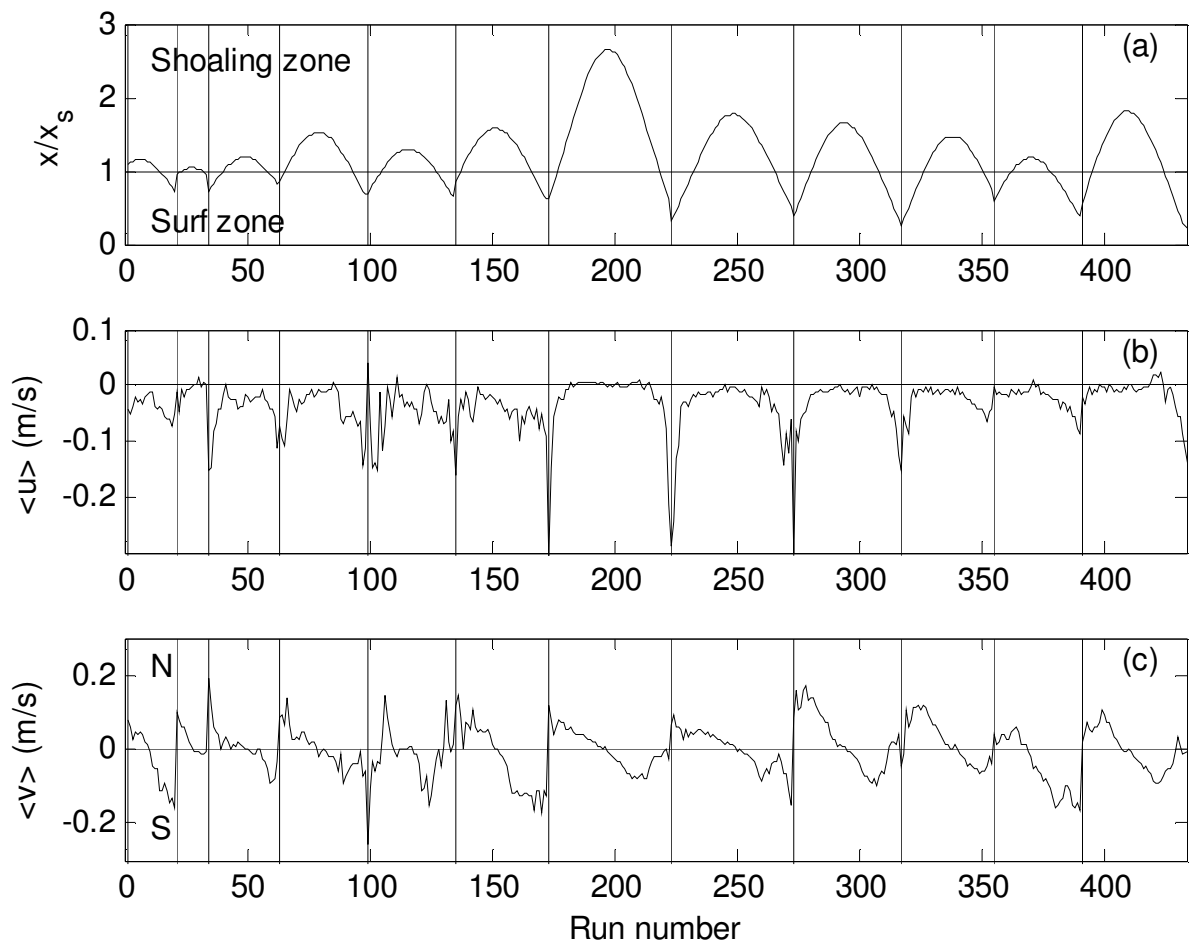

Fig. 6. (a) Distance from shore to the rig (x) normalised by the surf zone width $\left(\mathrm{x}_{\mathrm{s}}\right)$. Values of $\mathrm{x} / \mathrm{x}_{\mathrm{s}}<1$ indicate data inside the surf zone; (b) and (c) show run averaged cross-shore and longshore velocities respectively, as measured by the ADV. Negative cross-shore velocities indicate offshore directed flows. Positive longshore velocities indicate northerly directed flow.

Mean cross-shore velocities were close to zero in deep water. Offshore directed flow strengths increased in the surf zone, and were maximum in the mid surf zone. Un-normalised velocity skewness $\left.\left(<\mathrm{u}^{3}\right\rangle\right)$ was calculated from the oscillatory component of the cross-shore velocity $\left(\mathrm{u}^{\prime}\right)$ and is often used as an indicator of bedload transport in sediment transport models (e.g. Bailard, 1981). It contains information on both velocity variance, and on wave shape. Skewed waves typically have a shorter duration shoreward stroke than the seaward stroke, but the shoreward component is of greater magnitude, and this can give rise to a net shoreward sediment transport (Bagnold, 1940). The normalised velocity skewness was calculated following Elgar et al. (1998) as an indicator of wave shape:

$$
S_{u}=\frac{\left\langle u^{\prime 3}\right\rangle}{\left\langle u^{\prime 3}\right\rangle^{3 / 2}}
$$

This skewness parameter is linked to onshore bedform migration (Crawford and Hay, 2001). In this data, velocity skewness $\left(S_{\mathrm{u}}\right)$ was almost always positive, increased shoreward, and reached a maximum of 1.6 in the mid surf zone. 

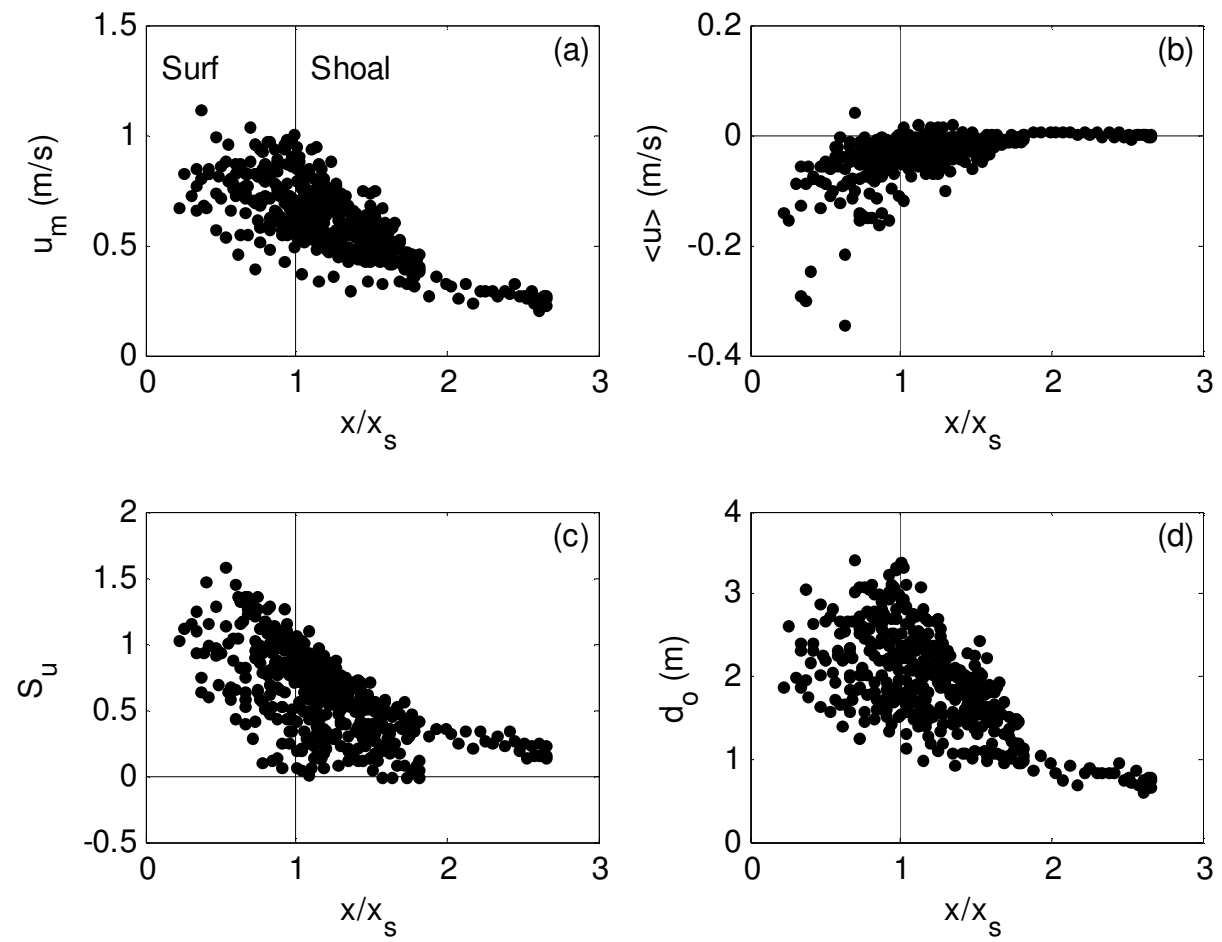

Fig. 7. Hydrodynamic parameters as a function of the normalised cross-shore position in the surf zone $\left(\mathrm{x} / \mathrm{x}_{\mathrm{s}}\right)$, showing (a) orbital velocity $\left(\mathrm{u}_{\mathrm{m}}\right)$; (b) mean crossshore current $(<\mathrm{u}>)$; (c) wave skewness $\left(\mathrm{S}_{\mathrm{u}}\right)$; and $(\mathrm{d})$ orbital diameter $\left(\mathrm{d}_{\mathrm{o}}\right)$.

Orbital excursion is often used as a predictor of bedform wavelength, which may in turn control the cross-shore distribution of bedform sizing observed by Clifton et al. (1971). The orbital diameter was calculated as twice the orbital amplitude $\left(\mathrm{d}_{\mathrm{o}}=2 \mathrm{~A}_{\mathrm{o}}\right)$, in which $\mathrm{A}_{\mathrm{o}}=\mathrm{u}_{\mathrm{m}} \mathrm{T}$ / $2 \pi$ (Soulsby, 1997). Here, orbital diameters were approximately $80 \mathrm{~cm}$ in deep water, and increased through the surf zone towards the shore, following the general trend of increasing bedform size observed by Clifton et al. (1971). The mobility number is commonly used as an indicator to delineate when surf zone bedforms develop (e.g. Gallagher et al., 2003):

$$
\psi=\frac{\left\langle u^{2}+v^{2}\right\rangle}{(s-1) g D}
$$

where $u$ and $v$ are the cross-shore and longshore velocities, $s$ is the specific gravity of the sediment (2.65 for quartz sand), $g$ is the gravitational acceleration and $D$ is the grain diameter. Generally $\psi$ was in the range 0 to 100 , and the cross-shore distribution followed the orbital velocity (Fig. 8). Gallagher et al. (2003) indicated that megaripples were flattened for $\psi>100$. In this data, bedforms were almost always present, presumably because the high stage flat-bed criteria was not exceeded. The mobility number was compared to a mobility 
number calculated with no longshore current $\left(\psi_{\mathrm{u}}\right)$ by setting $v=0$. The two forms of the mobility number showed close agreement $\left(\mathrm{R}^{2}=0.96\right)$. The relative contribution of the longshore current was quantified as $\psi=1.12 \psi_{\mathrm{u}}$.

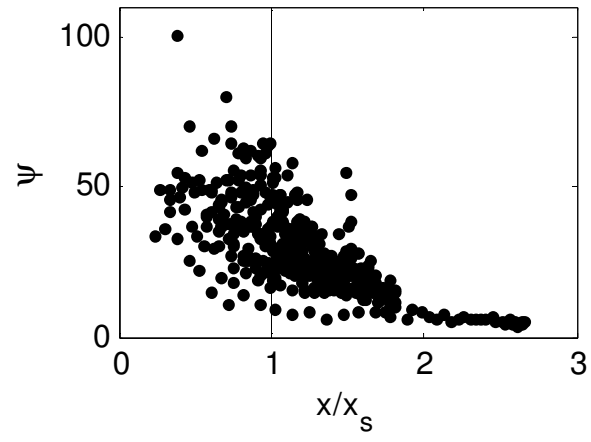

Fig. 8. Mobility number $(\psi)$ values and distribution across the shoaling and surf zone $\left(\mathrm{x} / \mathrm{x}_{\mathrm{s}}\right)$.

\section{Bedform observations}

\subsection{Wavelengths, heights and migration rates}

Sample scans from the SRP are shown in Fig. 9. Bedform wavelengths were calculated from individual bed profile scans as twice the spatial lag corresponding to the strongest negative auto-correlation peak, following Masselink et al. (2007) and Miles et al. (2014a). Bedform heights $(\eta)$ were quantified from the variance of the bed level over the SRP footprint (Crawford and Hay, 2001; Miles et al., 2014a):

$$
\eta=\sqrt{8 \sigma^{2}(z)}
$$

Bedform migration rates were calculated by cross-correlating time-separated bedform scans (Masselink et al., 2007). The lag associated with the largest correlation between the time separated scans was assumed to represent the distance the bed features had migrated between scans. Migration rates with low correlation coefficients $(<0.2)$ were discarded. A scan separation of 5 minutes gave migration rates consistent with visual observation of the raw time-separated scans.

The samples in Fig. 9 show bed profiles at $\mathrm{x} / \mathrm{x}_{\mathrm{s}}=2.5,1.75,1$ and 0.5 , representing 'average' wave condition measurements from outside the surf zone (run 201), the shoaling zone (run 250), the breakpoint (run 265) and the mid surf-zone (run 320). Orbital diameters $\left(\mathrm{d}_{\mathrm{o}}\right)$ are $0.7,1.5,1.8$ and $2.7 \mathrm{~m}$ respectively. To illustrate migration and bedform transport, two scans are shown for each location, separated by 20 minutes. Outside the surf zone (Fig. 9a), wave ripples with wavelength $(\lambda)$ of $\sim 20 \mathrm{~cm}$ and height $(\eta) \sim 2 \mathrm{~cm}$ are superimposed on stationary megaripples $(\lambda \sim 0.92 \mathrm{~m}, \eta \sim 6 \mathrm{~cm})$. In the shoaling zone (Fig. 9b), the wave ripple 
component has reduced, and the bedform $(\lambda \sim 1.18 \mathrm{~m}, \eta \sim 9 \mathrm{~cm})$ appears to be migrating shoreward slowly. At the breakpoint (Fig. 9c), the bedform height and steepness has increased $(\lambda \sim 1.13 \mathrm{~m}, \eta \sim 12 \mathrm{~cm})$, and shoreward migration is more rapid $\left(\mathrm{M}_{\mathrm{r}} \sim 0.28\right.$ $\mathrm{cm} / \mathrm{min}$ ). In the mid surf-zone (Fig. 9d), the ripple height reduces $(\lambda \sim 1.14 \mathrm{~m}, \eta \sim 6 \mathrm{~cm}$ ) as does the migration rate $\left(\mathrm{M}_{\mathrm{r}} \sim 0.12 \mathrm{~cm} / \mathrm{min}\right)$. The height and migration observations indicate bedform sediment transport rates are likely to be greatest in the region of the breakpoint.
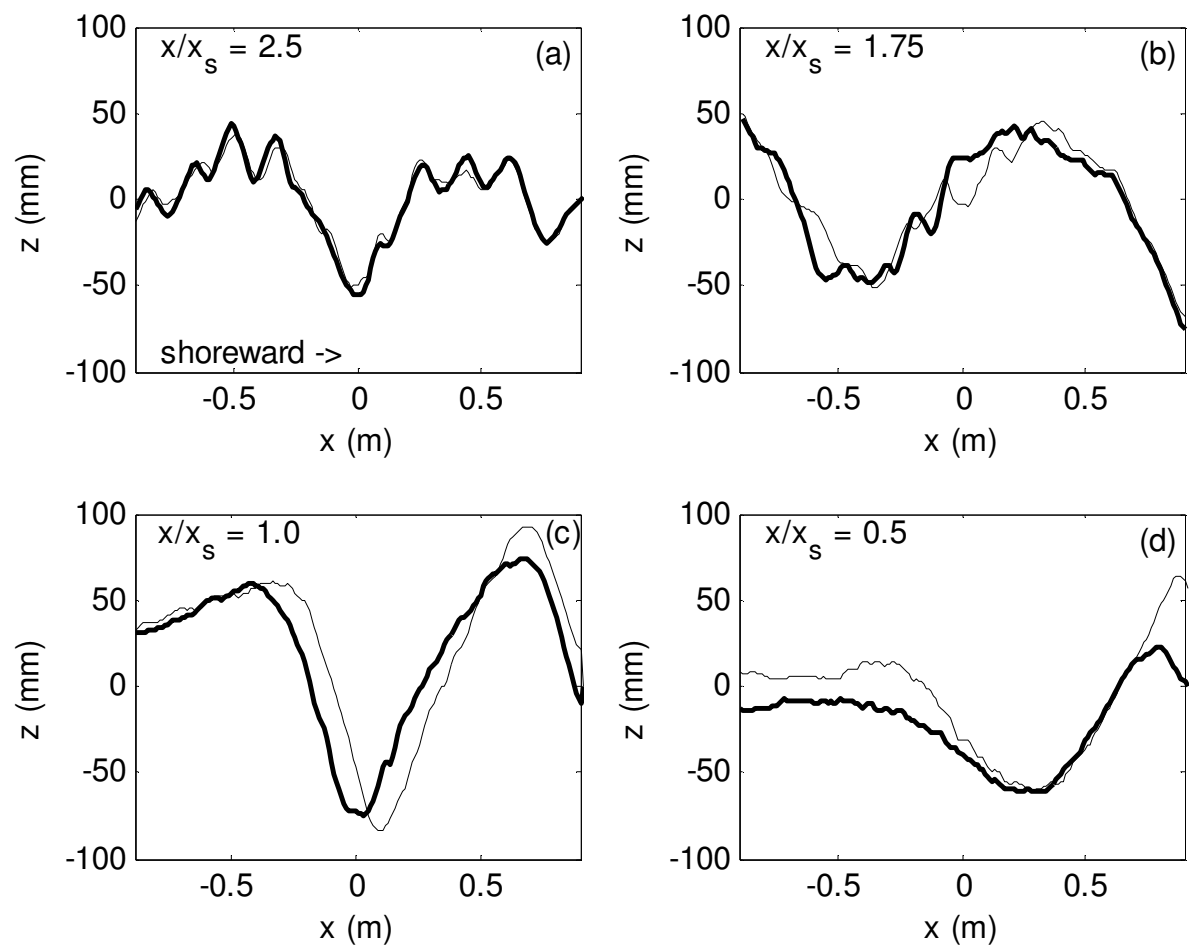

Fig. 9. Measured bedforms from (a) outside the surf zone ( $\left.x / x_{\mathrm{s}}=2.5\right)$; (b) seaward of the breakpoint $\left(\mathrm{x} / \mathrm{x}_{\mathrm{s}}=1.75\right)$; (c) at the breakpoint $\left(\mathrm{x} / \mathrm{x}_{\mathrm{s}}=1\right)$; and (d) in the mid surf zone $\left(\mathrm{x} / \mathrm{x}_{\mathrm{s}}=0.5\right)$. The 'fine' profile line is the measured profile 20 minutes after the 'bold' profile line.

For the complete dataset, the measured bedform wavelength $(\lambda)$ was in the range 48 to 272 $\mathrm{cm}$ (Fig. 10). The wavelength was weakly related to $\mathrm{u}_{\mathrm{m}}, \mathrm{d}_{\mathrm{o}}$ and mobility number. There is considerable spread in wavelengths across the surf zone $\left(\mathrm{x} / \mathrm{x}_{\mathrm{s}}\right)$, although there is some indication smaller wavelengths are observed outside the surf zone, and that larger wavelengths occur at approximately the breakpoint and just shoreward of the breakpoint.

The largest height bedforms developed when the orbital velocity was in the range 0.55 to $0.8 \mathrm{~m} / \mathrm{s}$, corresponding to a mobility number range of 20 to 50 (Fig. 11). Bedforms were at their maximum height when mean velocities were weak and directed offshore $(\sim-0.05 \mathrm{~m} / \mathrm{s})$. Bedform heights reduced below $10 \mathrm{~cm}$ when currents exceeded $0.15 \mathrm{~m} / \mathrm{s}$. Despite broad scatter, the data indicate that bedform heights increased shoreward towards the break point, 
the largest ripples developed in the region of the breakpoint, and heights then decrease through the surf zone.
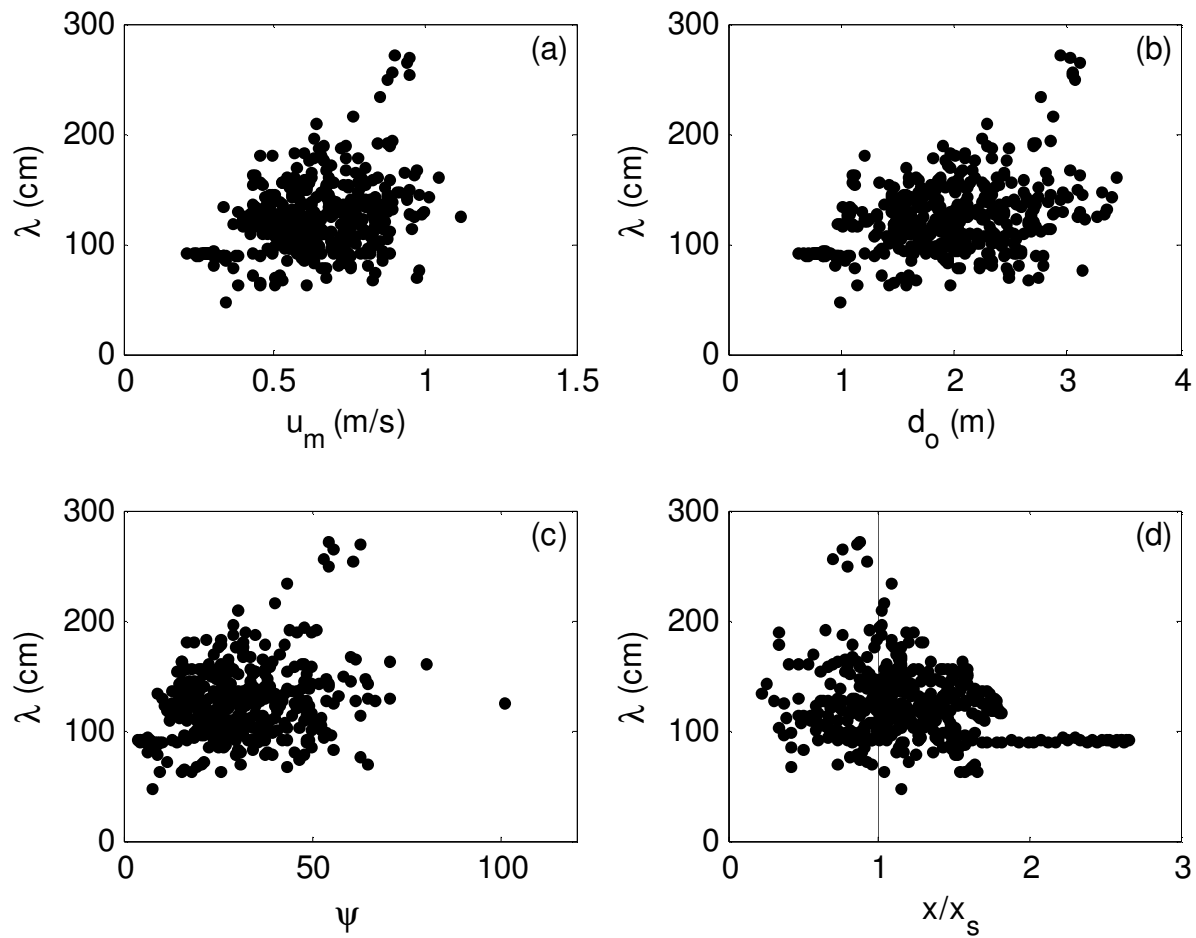

Fig. 10. Measured bedform wavelengths $(\lambda)$ as a function of (a) orbital velocity $\left(\mathrm{u}_{\mathrm{m}}\right)$; (b) orbital excursion $\left(\mathrm{d}_{\mathrm{o}}\right)$; (c) mobility number $(\psi)$; and (d) cross-shore position in the surf zone $\left(\mathrm{x} / \mathrm{x}_{\mathrm{s}}\right)$.

Bedforms were classified as sub-orbital $\left(12<\mathrm{d}_{\mathrm{o}} / \eta<100\right)$ or anorbital ripples $\left(\mathrm{d}_{\mathrm{o}} / \eta>100\right)$ (following Wiberg and Harris (1994)) and as vortex ripples $\left(\lambda / \mathrm{d}_{\mathrm{o}}<0.83\right)$ or post-vortex ripples $\left(\lambda / d_{o}>0.83\right)$ (following O'Hara Murray et al., (2011)). In Fig. 9, the bedforms in the shoaling and surf zones are suborbital, vortex ripples. Outside the surf zone $\left(x / x_{s}>2.5\right)$, a reduced orbital excursion gives these features a classification of sub-orbital, post vortex ripples.

The cross-shore distribution of the classification parameters is shown in Fig 12. For the majority of the data, ripples were classified as sub-orbital. The ratio $d_{0} / \eta$ was approximately maximum near the breakpoint, where orbital velocities were largest compared to the ripple height. A few data points indicate anorbital ripples in the outer surf zone, as a result of larger orbital velocities and smaller bedform heights in certain sections of the data. The data suggests that in the surf zone, ripples are generally vortex ripples. Outside the surf zone, bedform wavelengths are large compared to orbital excursions, suggesting post-vortex ripples. Growth beyond orbital excursion may result from self-organisation (Miles et al., 
2014b), or arise from a lag in ripple response after a change in hydrodynamic conditions (Austin et al., 2007). Analysis of both parameters suggests suborbital vortex ripples existed for 304 of the 433 runs (i.e. $70 \%$ of the time), suborbital post vortex ripples existed for 119 runs $(27 \%)$, and anorbital, post-vortex ripples were present for 9 runs $(2 \%)$.
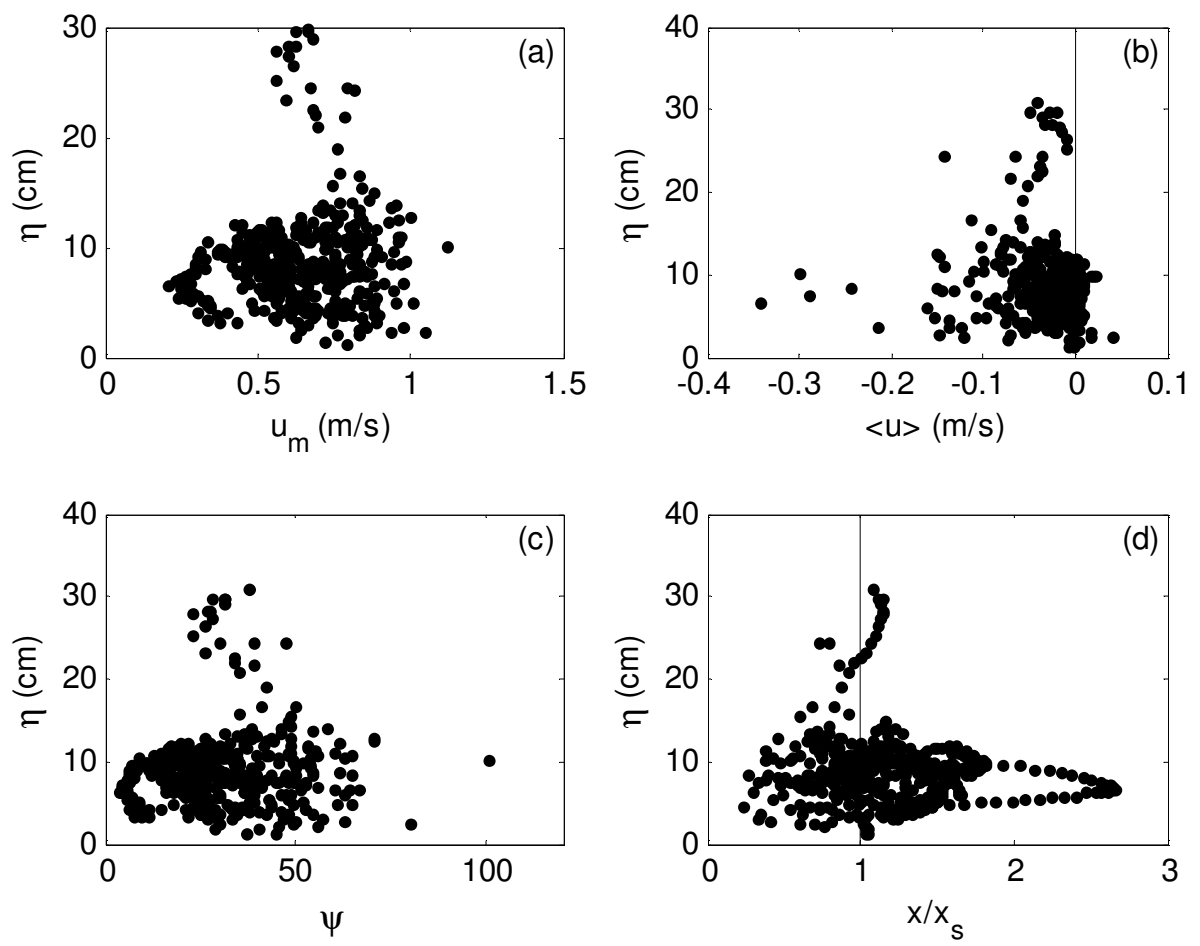

Fig. 11. Measured ripple heights $(\eta)$ as a function of (a) orbital velocity $\left(u_{m}\right)$; (b) mobility number $(\psi)$; (c) mean flow strength $(<\mathrm{u}>)$; and $(\mathrm{d})$ cross-shore position in the surf zone $\left(\mathrm{x} / \mathrm{x}_{\mathrm{s}}\right)$.

The cross-shore distribution of the classification parameters are shown in Fig 12. For the majority of the data, ripples were classified as sub-orbital. The ratio $d_{o} / \eta$ was approximately maximum near the breakpoint, where orbital velocities were largest compared to the ripple height. A few data points indicate anorbital ripples in the outer surf zone, as a result of larger orbital velocities and smaller bedform heights in certain sections of the data. The data suggests that in the surf zone, ripples are generally vortex ripples. Outside the surf zone, bedform wavelengths are large compared to orbital excursions, suggesting post-vortex ripples. Growth beyond orbital excursion may result from self-organisation (Miles et al., 2014 b), or arise from a lag in ripple response after a change in hydrodynamic conditions (Austin et al., 2007). Analysis of both parameters suggests suborbital vortex ripples existed for 304 of the 433 runs (i.e. $70 \%$ of the time), suborbital post vortex ripples existed for 119 runs $(27 \%)$, and anorbital, post-vortex ripples were present for 9 runs $(2 \%)$. 

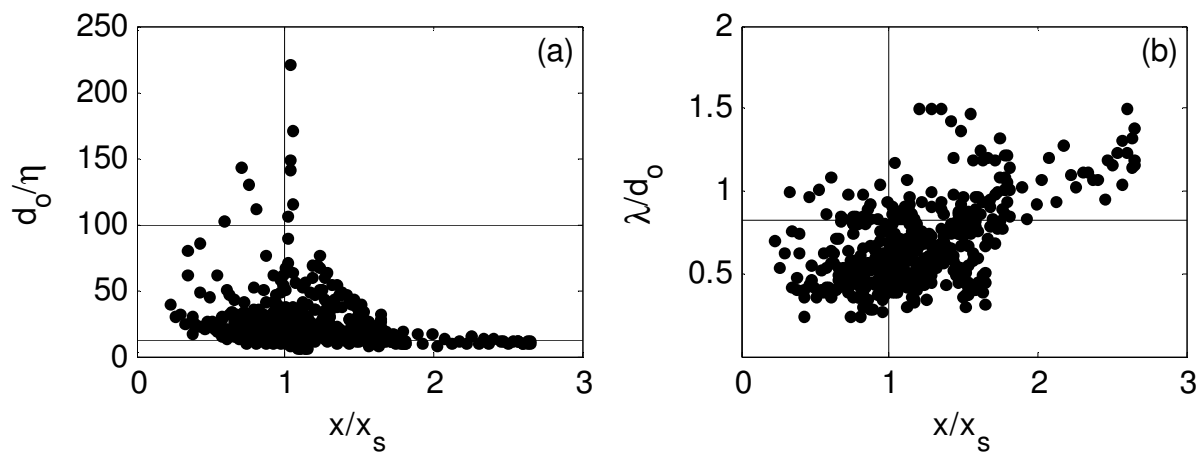

Fig. 12. Cross-shore distribution of bedform classification parameters (a) $d_{o} / \eta$; and (b) $\lambda / d_{0}$. Values of $12<\mathrm{d}_{\mathrm{o}} / \eta<100$ indicate sub-orbital ripples, $\mathrm{d}_{\mathrm{o}} / \eta>100$ indicates anorbital ripples (Wiberg and Harris, 1994). Values of $\lambda / \mathrm{d}_{0}<0.83$ indicate vortex ripples (O’Hara Murray et al., 2011).

Bedform migration $\left(\mathrm{M}_{\mathrm{r}}\right)$ was found to be predominantly onshore-directed, and up to 1.5 $\mathrm{cm} / \mathrm{min}$ (Fig. 13). Shoreward migration rates generally increased with wave velocity skewness, despite scatter in the data. Migration rates generally increased with increasing orbital velocities. Onshore-directed migration reduced as the offshore-directed mean flow speed increased. Shoreward migration of megaripples was halted when offshore-directed mean flows were $>\mid 0.15 \mathrm{I} \mathrm{m} / \mathrm{s}$. These data suggest that the resultant migration direction (onshore / halted / offshore) depends on the competition between velocity skewness, orbital velocity and mean flow, and this is controlled in turn by position in the surf zone. Bedforms generally migrated most quickly just shoreward of the breakpoint. This co-incided with times when the wave orbital velocities were large, when the wave skewness was increasing onshore, and when the mean current was not too strongly offshore to reduce migration rates.

\subsection{Bedform sediment transport}

Bedform sediment transport rates $\left(\mathrm{Q}_{\mathrm{b}}\right)$ were calculated using the Huntley et al. (1991) approach:

$$
Q_{b}=0.5(1-p) \rho \eta M_{r}
$$

where $p$ is a packing factor (0.35) (Traykovski et al., 1999), $\rho$ is the sediment density (2650 $\mathrm{kg} / \mathrm{m}^{3}$ ), $\eta$ is the bedform height and $M_{r}$ is the bedform migration rate. Bedform sediment transport rates were generally onshore directed. Bedform transport rates followed similar general trends to the bedform migration rates, increasing with increased wave skewness, wave orbital velocity and with mobility number (Fig. 14). The maximum transport rate was $0.021 \mathrm{~kg} / \mathrm{m} / \mathrm{s}$. Since the shoreward bedform sediment transport is intrinsically linked 
to migration rate, the shoreward bedform sediment transport was halted when offshoredirected mean currents strengths were $>10.15 \mid \mathrm{m} / \mathrm{s}$.
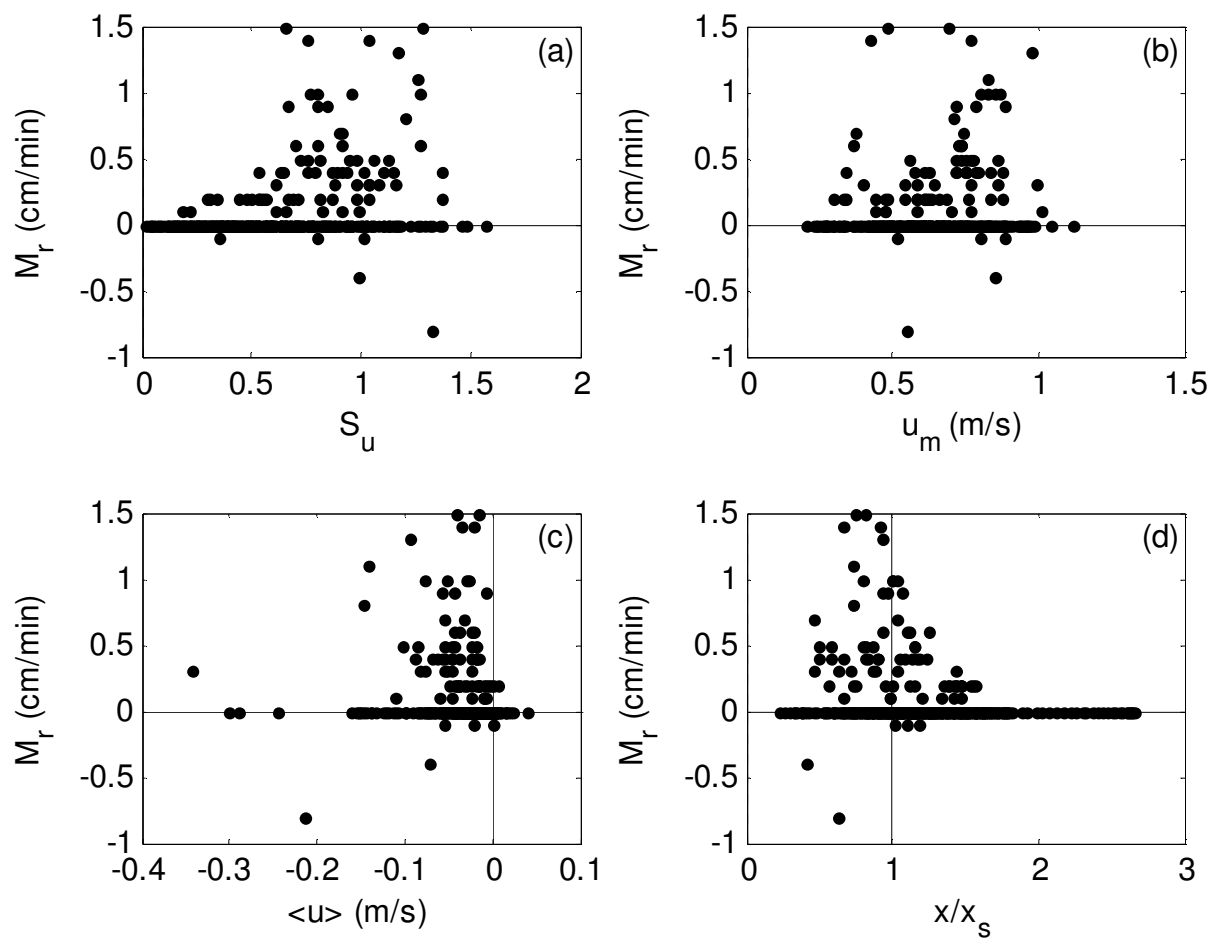

Fig. 13. Ripple migration rate $\left(M_{r}\right)$ compared to (a) cross-shore velocity skewness $\left(\mathrm{S}_{\mathrm{u}}\right)$; (b) orbital velocity $\left(\mathrm{u}_{\mathrm{m}}\right)$; (c) mean flow strength $(<\mathrm{u}>)$; and (d) cross-shore position in the surf zone $\left(\mathrm{x} / \mathrm{x}_{\mathrm{s}}\right)$.

The cross-shore distribution of bedform transport indicated that onshore transport peaked in the surf zone at $\mathrm{x} / \mathrm{x}_{\mathrm{s}}=0.8$ (Fig. 15). In the inner surf zone $\left(\mathrm{x} / \mathrm{x}_{\mathrm{s}}<0.5\right)$ and in the shoaling zone $\left(\mathrm{x} / \mathrm{x}_{\mathrm{s}}>1.5\right)$ the magnitude of the bedform contribution was small compared to that of the breakpoint region. There is scatter in the data, and at times, even at the breakpoint, the transport rates were small. 

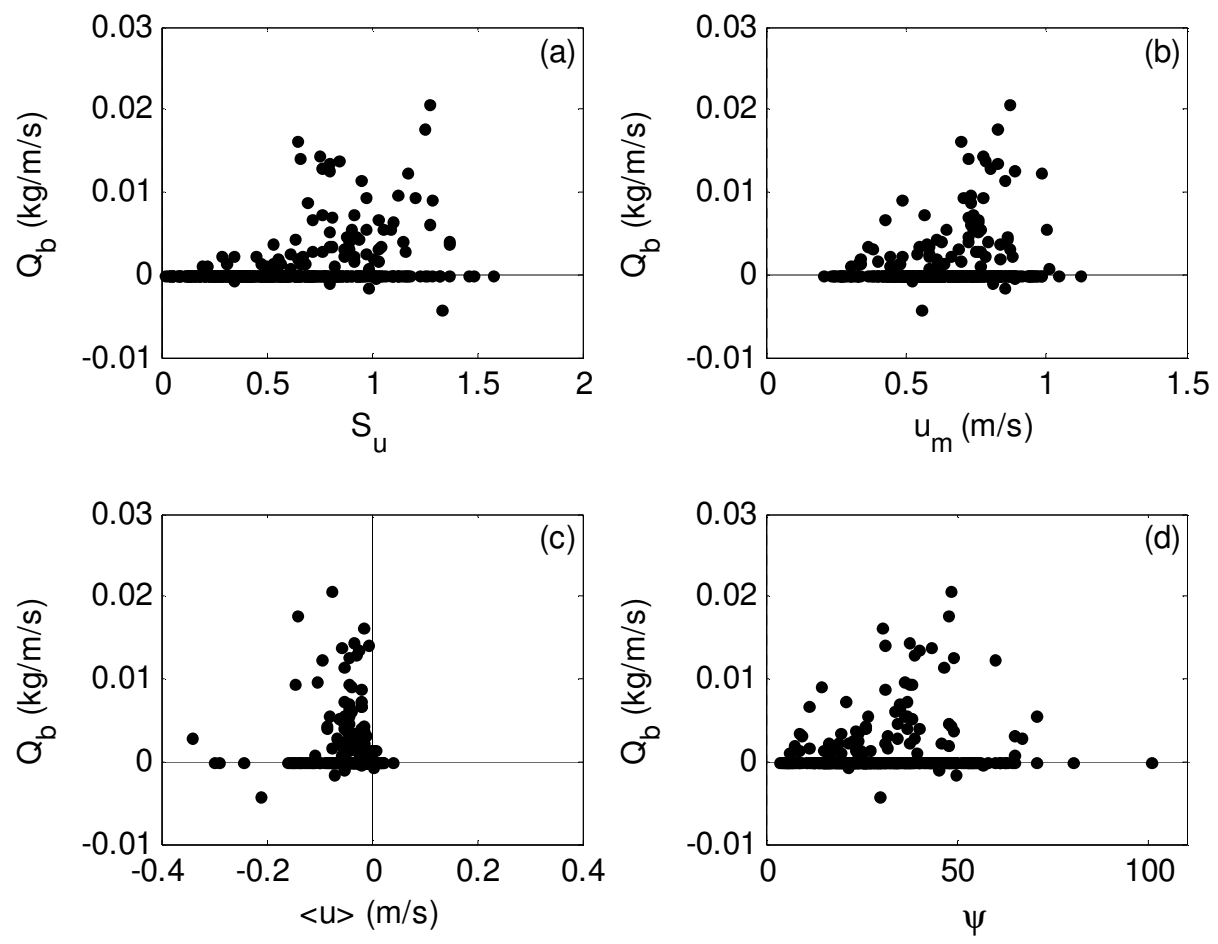

Fig. 14. Bedform sediment transport rate $\left(\mathrm{Q}_{\mathrm{b}}\right)$ compared to (a) cross-shore velocity skewness $\left(\mathrm{S}_{\mathrm{u}}\right)$; (b) orbital velocity $\left(\mathrm{u}_{\mathrm{m}}\right)$; (c) mean flow strength $(<\mathrm{u}>)$; and (d) mobility number $(\psi)$.

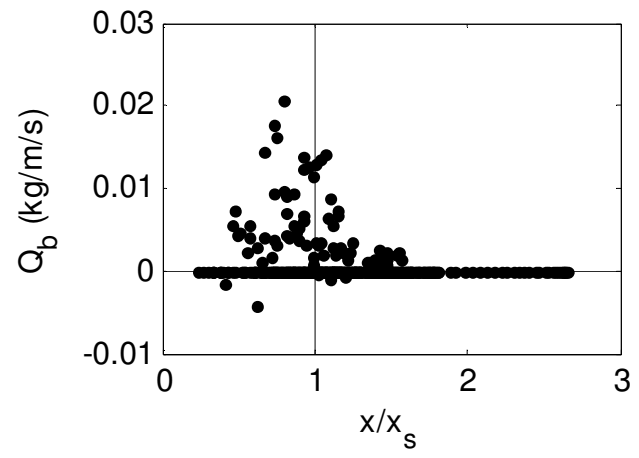

Fig. 15. Bedform transport rate $\left(\mathrm{Q}_{\mathrm{b}}\right)$ variation with cross-shore position in the surf zone $\left(\mathrm{x} / \mathrm{x}_{\mathrm{s}}\right)$.

\section{Suspended sediment transport observations}

In the first 6 tides measured, suspended sediment concentrations were measured at OBS heights of $\mathrm{z}_{1}=5 \mathrm{~cm}$ and $\mathrm{z}_{2}=15 \mathrm{~cm}$ above the bed, while in the second six tides measured, 
OBSs were set at $25 \mathrm{~cm}$ and $40 \mathrm{~cm}$. Mean and oscillatory components of sediment transport rates are calculated here for a height of $25 \mathrm{~cm}$ above the bed, to allow for comparison between the runs across the 12 tides. For rippled beds, Nielsen (1988) gives the variation in concentration (c) with distance from the bed $(\mathrm{z})$ in terms of $\mathrm{c}_{0}$, a reference concentration at the bed, and $L_{\mathrm{s}}$, a length-scale representing the vertical diffusivity of the sediment.

$$
c_{z}=c_{0} e^{-z / L_{s}}
$$

Run-averaged values of concentration at the two heights measured were used to calculate run-averaged values of $L_{s}$ :

$$
L_{s}=\frac{z_{2}-z_{1}}{\log \left\langle c_{1}\right\rangle-\log \left\langle c_{2}\right\rangle}
$$

A concentration time series at a third height, $\left(\mathrm{z}_{3}=25 \mathrm{~cm}\right)$, was calculated for the first six tides from the measured OBS data $\left(\mathrm{z}_{1}=5 \mathrm{~cm}\right)$ using:

$$
c_{3}=c_{1} \frac{e^{-z_{3} / L_{s}}}{e^{-z_{1} / L_{s}}}
$$

This approach also allows concentrations to be predicted at other heights in the water column, to allow a total load calculation to be made.

Time-averaged sediment concentrations at $25 \mathrm{~cm}$ indicated that the largest concentrations occurred in the shallow water at the start and end of each tide, and this corresponded to lower values of $\mathrm{x} / \mathrm{x}_{\mathrm{s}}$ in the inner surf zone (Fig. 16).

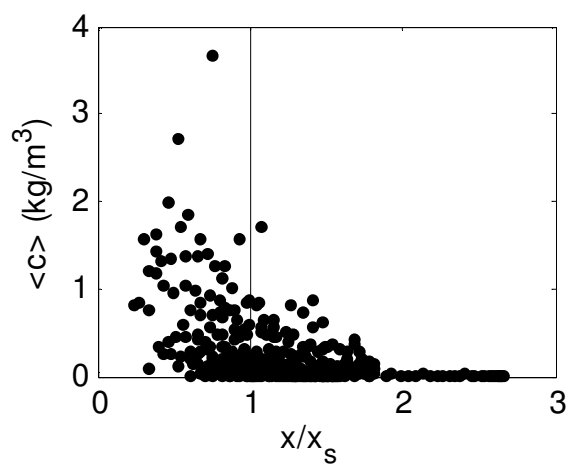

Fig. 16. Mean sediment concentrations $(<c>)$ at $\mathrm{z}=25 \mathrm{~cm}$ above the bed, at different cross-shore positions in the surf zone $\left(\mathrm{x} / \mathrm{x}_{\mathrm{s}}\right)$.

The time-averaged depth specific (i.e. $\mathrm{z}=25 \mathrm{~cm}$ ) 'total' sediment transport $(<\mathrm{uc}>$ ) was separated into mean $(<\mathrm{u}><\mathrm{c}>)$ and oscillatory components following Jaffe et al. (1984). Oscillatory components of velocity and concentration data were high-pass and low-pass filtered at $0.05 \mathrm{~Hz}$, to identify the relative importance of gravity $\left\langle\mathrm{u}_{\mathrm{g}}{ }^{\prime} \mathrm{c}_{\mathrm{g}}{ }^{\prime}>\right.$ and infragravity 
$<\mathrm{u}_{\mathrm{ig}}{ }^{\prime} \mathrm{c}_{\mathrm{ig}}{ }^{\prime}>$ components of the transport respectively (e.g. Wright et al., 1991). The total transport was therefore considered as:

$$
\langle u c\rangle=\langle u\rangle\langle c\rangle+\left\langle u_{g}^{\prime} c_{g}^{\prime}\right\rangle+\left\langle u_{i g}^{\prime} c_{i g}^{\prime}\right\rangle
$$

The incident wave component was variable in direction (Fig. 17), but was the only suspended transport component to give onshore transport. The infragravity frequency suspended sediment transport was generally offshore directed in the surf zone. The mean component of transport was offshore directed, dominated the transport rates, and increased in magnitude shoreward. The total transport therefore, was offshore directed, and measured transport rates were larger when the rig was closer to the shore.
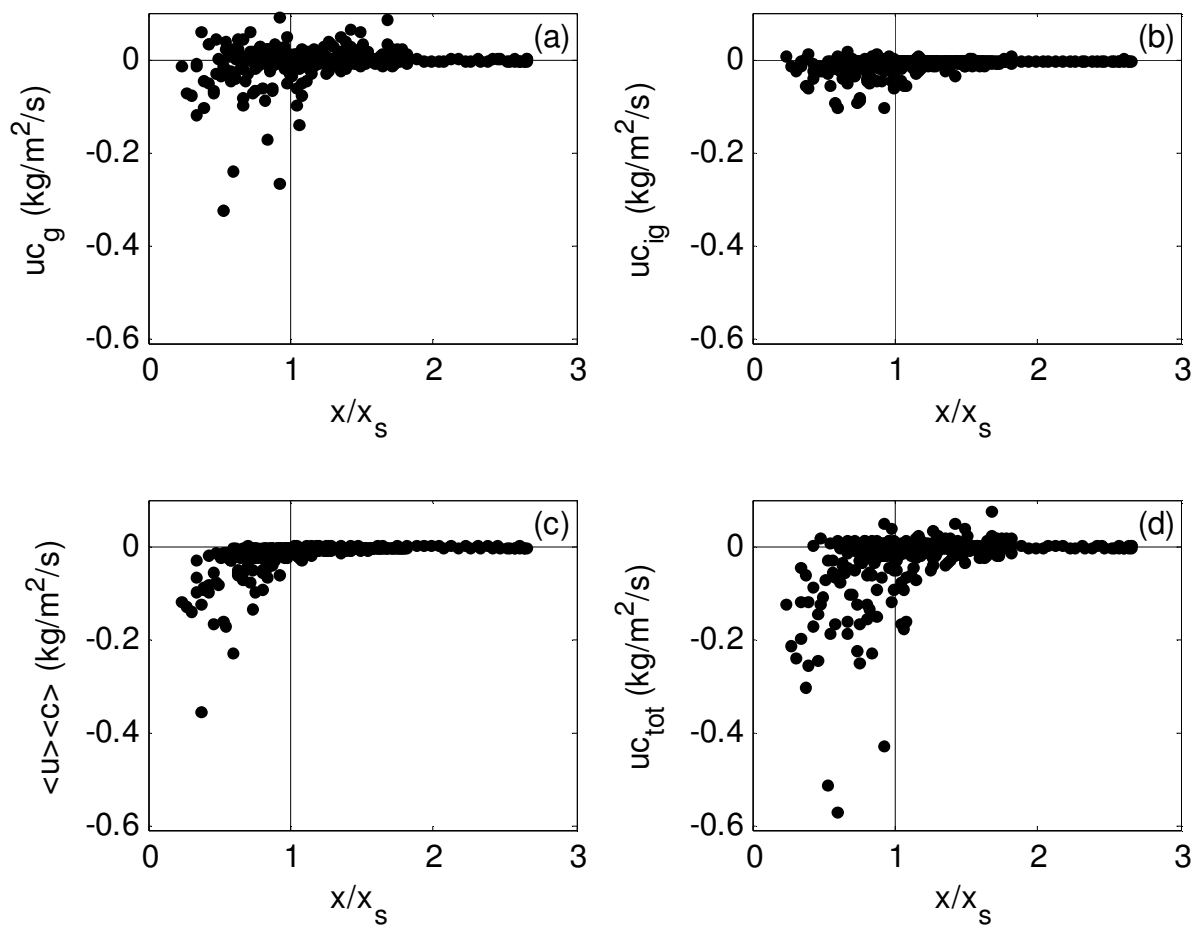

Fig. 17. Cross-shore distribution of sediment transport rates at $\mathrm{z}=25 \mathrm{~cm}$ above the bed. Components shown are (a) incident wave $\left(\mathrm{uc}_{\mathrm{g}}\right)$; (b) infragravity $\left(\mathrm{uc}_{\mathrm{ig}}\right)$; (c) mean $(<\mathrm{u}><\mathrm{c}>)$ and $(\mathrm{d})$ total $\left(\mathrm{uc}_{\mathrm{tot}}\right)$.

Despite the apparent link between velocity skewness and bedform migration, there was low correlation between bedform migration and suspended sediment transport. This is possibly because although wave skewness appears to be a key variable in driving bedform migration, the suspended sediment transport is much more sensitive to the offshore directed mean flow. 


\section{Relative Contributions of Bedform and Suspended Sediment Transport}

The total depth integrated sediment transport was estimated for each run following the general approach of Aagard et al. (2012). The sediment concentration profile was calculated with a vertical resolution of $1 \mathrm{~cm}$ for each time step of the data using the Nielsen (1988) equation, based on the concentrations at $25 \mathrm{~cm}$ height. It was not appropriate to extrapolate the concentration profiles below the $25 \mathrm{~cm}$ height, because this would increase the transport rates beyond those measured in the second six tides, so the concentration profile below $25 \mathrm{~cm}$ was assumed to be equal to the concentration at $25 \mathrm{~cm}$. It is acknowledged that the technique is likely to result in an underestimation of the total suspended load.

A velocity profile corresponding to the suspended sediment profile was calculated by assuming that velocities above the ADV were equal to those measured at the ADV, and below the ADV, the velocity was gradually reduced to zero at the bed using the Van-Rijn (1993) equation:

$$
u=u_{A D V}\left(\frac{z}{z_{A D V}}\right)^{0.25} \quad \text { for } 0<\mathrm{z}<\mathrm{z}_{\mathrm{ADV}}
$$

At each time step, a flux profile was obtained from the velocity profile and concentration profile. This was integrated to obtain a time series of the depth integrated sediment flux:

$$
Q_{s}(t)=\sum_{z=0}^{z=h}(u(t, z) c(t, z)) d z
$$

From this, the average depth integrated sediment transport rate $\left(\mathrm{Q}_{\mathrm{s}}\right)$ was calculated, with units of $\mathrm{kg} / \mathrm{m} / \mathrm{s}$, such that comparison could be made with the bedform transport rates.

The depth integrated suspended load transport takes a similar form to the point measurements (Fig. 18). Offshore-directed transport rates due to the suspended component reached $-0.18 \mathrm{~kg} / \mathrm{m} / \mathrm{s}$ in the mid surf zone. Maximum bedform transport rates were an order of magnitude less than this (up to $0.021 \mathrm{~kg} / \mathrm{m} / \mathrm{s}$ ) (Fig. 15), but peaked slightly further seaward than the suspended load. Like the bedform transport data, there were times when the depth integrated total transport was zero, and these instances give opportunity for the relative contribution of bedform transport to dominate.

The total transport $\left(\mathrm{Q}_{\mathrm{s}}+\mathrm{Q}_{\mathrm{b}}\right)$ and the relative magnitude of the bedform transport to the total of the absolute transports are shown in Fig. 19. In the shoaling zone, the total transport $\left(\mathrm{Q}_{\mathrm{s}}+\mathrm{Q}_{\mathrm{b}}\right)$ was small and variable in direction. In the surf zone the transport was generally offshore directed (up to $-0.16 \mathrm{~kg} / \mathrm{m} / \mathrm{s}$ ), and was maximum in the mid-surf zone. The relative contribution of bedform transport was identified by comparing the absolute bedform transport to the sum of absolute bedform and suspended components $\left(\left|Q_{b}\right| /\left|Q_{b}\right|+\left|Q_{s}\right|\right)$. The spread in the data is probably because both the ripple migration and suspended sediment transport 
events were episodic, and high transport rates in either component did not necessarily coincide. Data was therefore further binned into sections of $\mathrm{x} / \mathrm{x}_{\mathrm{s}}$ of width 0.25 , and the average value of the $\mathrm{Q}_{\mathrm{b}}$ contribution calculated for these binned sections. This analysis is indicated by the solid line in Fig. 19b. Well beyond the surf zone, $\left(\mathrm{x} / \mathrm{x}_{\mathrm{s}}>1.5\right)$ the bedform component was small, because migration rates were small there. The bedform contribution increased in the region approaching the surf zone, at the breakpoint, and in the outer part of the surf zone when bedforms were mobile. The maximum average bedform contribution from the bin averaging was $14.6 \%$ (at $\mathrm{x} / \mathrm{x}_{\mathrm{s}}=0.9$ ). The contribution of bedforms diminished in the mid to inner surf zone, where the suspended load dominated.

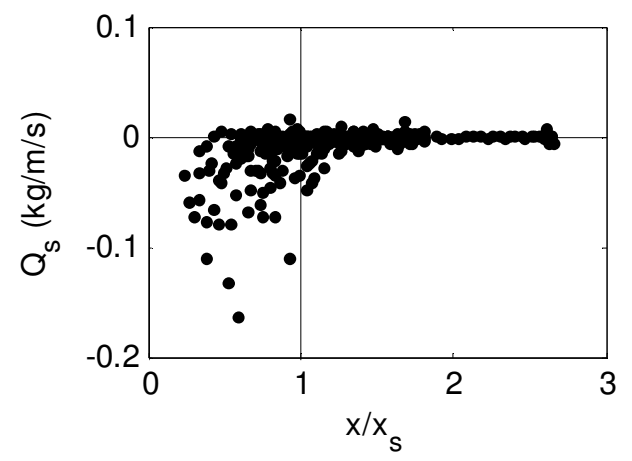

Fig. 18. Cross-shore distribution of depth integrated cross-shore sediment transport $\left(\mathrm{Q}_{\mathrm{s}}\right)$.
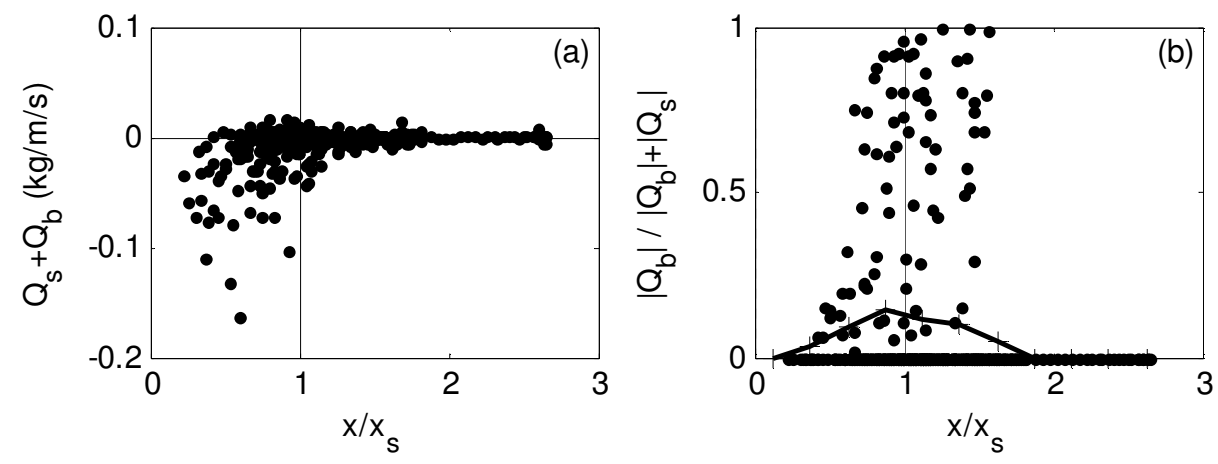

Fig. 19. Cross-shore distribution of (a) the total suspended $\left(\mathrm{Q}_{\mathrm{s}}\right)$ and bedform $\left(\mathrm{Q}_{\mathrm{b}}\right)$ transport; and (b) the relative contribution of bedform transport to the sum of the absolute transport rates. The solid line in (b) indicates the bin averaged contribution of bedforms, with (+) points indicating the mid points of the averaged values. 


\section{Discussion}

On a reflective beach $\left(\mathrm{D}_{50}=0.25\right.$ to $\left.0.3 \mathrm{~mm}\right)$ in 'storm' conditions, Aagard et al. (2013) measured wave ripple heights with an average of $8 \mathrm{~cm}$. The average ripple wavelength was $85 \mathrm{~cm}$, and steepness 0.09. In smaller waves, the ripples were larger in height but shorter (average height $9.7 \mathrm{~cm}$, length $68 \mathrm{~cm}$, steepness 0.14). On an intermediate macrotidal beach, Masselink et al. (2007) measured ripples with elevation $5 \mathrm{~cm}$ and length $35 \mathrm{~cm}$, although the grain sizes were more coarse $\left(\mathrm{D}_{50}=0.7 \mathrm{~mm}\right)$ than those measured at the site of Aagard et al. (2013) and here. At Duck94, Ngasuru and Hay (2004) measured bedforms that were 20-40 $\mathrm{cm}$ high with wavelengths of $1-2 \mathrm{~m}$ in the trough between the beach and the first sandbar. Traykovski et al.'s (1999) measurements in $11 \mathrm{~m}$ water depth indicate ripples of height 15 $\mathrm{cm}$, and length $100 \mathrm{~cm}$. The data here suggests ripple lengths of similar order to Traykovski et al. (1999) ( 1 m) in deep water, that become larger in the surf zone (up to $\sim 1-2 \mathrm{~m}$ ), in line with observations by Ngasuru and Hay (2004) in the trough of a sandbar system, and coincidental with the measured increase in orbital velocities and orbital diameter in the surf zone.

Bedforms in this experiment generally migrated shoreward and in the direction of positive skewness, as observed by Crawford and Hay (2001) and Doucette (2002). In terms of crossshore distribution, Masselink et al. (2007) also observed strong dependency on cross-shore position on their intermediate beach, with onshore migration in the shoaling zone $(0.1 \mathrm{~cm} /$ min), an increase in migration rate at the breakpoint to $2 \mathrm{~cm} / \mathrm{min}$, and reduced rates in the inner surf zone. These values are of similar magnitude to the maximum migration rate observed here of $1.5 \mathrm{~cm} / \mathrm{min}$. Onshore migration in the surf zone is likely to be reduced by both a decrease in wave skewness, and also an increase in the mean offshore flow, as observed by Ngasuru and Hay (2004).

The bedform sediment transport rate calculation has been shown to give reasonable agreement with bedload transport models by Hay and Bowen (1993) and Traykovski et al. (1999). In high energy conditions however, bedload transport may take place as sheet flow, and may bypass any bedforms. This form of transport will be missed by OBSs higher in the water column, and will not be included in bedform sediment transport values using the method presented here.

It is acknowledged that higher resolution velocity profile and suspended sediment concentration data would improve the accuracy of the vertically integrated suspended sediment transport calculations. A pragmatic approach is applied here, based on the available instrumentation. Masselink et al. (2007) used a dense array of OBSs in the nearbed region of Sennen beach (Cornwall, UK), with a vertical spacing of $\sim 1 \mathrm{~cm}$, and Electromagnetic Current meters with a vertical spacing of $\sim 3 \mathrm{~cm}$. They observed suspended sediment transport rates of up to $0.15 \mathrm{~kg} / \mathrm{m} / \mathrm{s}$ in the break region in calm conditions and up to $0.6 \mathrm{~kg} / \mathrm{m} / \mathrm{s}$ in storm $(\mathrm{H}=2$ m) conditions, compared to rates of up to $0.18 \mathrm{~kg} / \mathrm{m} / \mathrm{s}$ here. The data here are from broadly similar incident wave conditions to Masselink et al. (2007), but it is likely that the values here offer a conservative estimate, because of the height of the reference concentration 
measurement. Differences will also occur because Perranporth beach is less steep than Sennen, and Perranporth has finer grain sizes.

In contrast, Aagard et al. (2012, 2013) used an Acoustic Doppler Profiler (ADP) to measure vertically integrated transport rates on a reflective beach. Aagard et al.'s (2012) ADP had a vertical resolution of $1.6 \mathrm{~cm}$, and measurements were made in storm conditions $(\mathrm{H}=0.9 \mathrm{~m}$ at the site $)$ and in post-storm $(\mathrm{H}=0.45 \mathrm{~m}$ at the site $)$ conditions over sand with $\mathrm{D}_{50}$ of $0.25 \mathrm{~mm}$ to $0.3 \mathrm{~mm}$. Vertically integrated suspended sediment transport rates were an order of magnitude less, with transport rates of $-0.022 \mathrm{~kg} / \mathrm{m} / \mathrm{s}$ in the storm conditions, and $0.0048 \mathrm{~kg} / \mathrm{m} / \mathrm{s}$ in the post storm conditions. Aagard et al. (2012) identified that the difference between their data and Masselink et al.'s (2007) data was probably because Masselink et al. (2007) had larger wave heights, and extended into shallower water. In the more calm periods in this experiment, and in deeper water, the vertically integrated suspended sediment transport rates were in the region of 0 to $0.01 \mathrm{~kg} / \mathrm{m} / \mathrm{s}$, and are therefore broadly in line with those of Aagard et al. (2012).

The results here contrast the observations of Traykovski et al. (1999) from water $11 \mathrm{~m}$ deep, in which the bedform component of transport was an order of magnitude larger than the suspended component. In the deepest water of this data $(6 \mathrm{~m})$ the bedform transport was small compared to the suspended component. The grain sizes in Traykovski's data were rather more coarse $\left(\mathrm{D}_{50}=0.33\right.$ to $\left.0.465 \mathrm{~mm}\right)$, and both the mean currents and orbital velocities were smaller than in this experiment, which would lead to a reduction in the sediment in suspension and available for transport at Traykovski's site.

Over the past decades, much research has focused on the suspended component of transport, partly due to the opportunities offered by the evolution of the Optical Backscatter Sensor, and partly because key models such as the energetics model of Bailard (1981) indicate that the suspended load becomes dominant in the surf zone. These approaches led to the suggestion of a cross-shore shape to the suspended sediment transport in the surf zone, with onshore transport in the shoaling zone (driven by wave skewness) and offshore transport in the surf zone (driven by undertow and an infragravity component) (Osborne and Greenwood, 1992; Russell and Huntley, 1999; Tinker et al., 2009). The observations here suggest that there is also a cross-shore structure in the relative contribution of bedforms to the transport.

Wave skewness has been shown to contribute to the shoreward migration of sandbars (Gallagher et al., 1998a), and it is possible that at least part of the link from wave skewness to onshore sandbar migration and beach recovery happens through the onshore migration of bedforms. Further field measurements may therefore usefully focus on the contribution of bedforms in accretionary conditions. This will require a more dense array of nearbed currents and sediment concentrations than possible using the data from this experiment.

The dissipative morphological conditions in this dissipative beach experiment contrast the intermediate beach data of Masselink et al. (2007) and the steep beach data of Aagard et al. (2012). For the steep beach measurements made by Aagard et al. (2012), in large waves the suspended load dominated the transport and was offshore directed, while in smaller waves the 
onshore component contributed by the bedforms gained importance. In the intermediate case of Masselink et al. (2007), in large waves and in the surf zone, the suspended load dominated, and the total transport was offshore directed. In low waves, the bedform transport rates were of greater importance and were shoreward directed. Data here from the dissipative beach conceptually support these observations, despite the different morphodynamic beach classifications. Furthermore, the observations suggest that the inclusion of bedforms may be of particular importance for modelling shoreward transport associated with beach recovery, but may be less important for modelling erosion during storms.

\section{Conclusions}

Bedforms with heights up to $30 \mathrm{~cm}$ and wavelengths from 0.5 to $2.7 \mathrm{~m}$ were observed to develop on a sandy dissipative beach in wave heights 0.5 to $2.2 \mathrm{~m}$. Bedform wavelengths generally increased shoreward through the shoaling zone, and the maximum wavelengths observed were positioned just shoreward of the breakpoint. Although a pattern in the crossshore distribution of ripple heights was not clear, the envelope of data suggested that maximum heights increased towards the breakpoint, and that the maximum heights were observed in the region of the breakpoint. Bedforms were classified as sub-orbital, vortex ripples. Bedform migration was onshore directed, and correlated with wave skewness. Through the shoaling zone, migration rates increased, and reached a maximum of $1.5 \mathrm{~cm} / \mathrm{min}$ just shoreward of the breakpoint. Migration rates reduced shoreward of this. Sediment transport rates associated with the bedforms were onshore directed, increased shoreward through the shoaling zone, to a maximum of $0.021 \mathrm{~kg} / \mathrm{m} / \mathrm{s}$ just shoreward of the breakpoint.

Point measurements showed that the cross-shore suspended sediment transport $25 \mathrm{~cm}$ above the bed was dominated by the mean component, with an offshore directed maximum at $\mathrm{x} / \mathrm{x}_{\mathrm{s}}=0.5$. Contributions to onshore transport were only made by the incident waves. The total depth integrated suspended sediment transport was offshore directed and maximum in the mid surf zone $(-0.16 \mathrm{~kg} / \mathrm{m} / \mathrm{s})$. The depth integrated suspended sediment transport dominated over the bedform sediment transport in the inner to mid surf zone $\left(x / x_{s}<0.5\right)$ and in the outer shoaling zone $\left(\mathrm{x} / \mathrm{x}_{\mathrm{s}}>1.5\right)$. Although the fractional contribution of the shoreward directed bedform transport to the total absolute transport was up to $100 \%$ for any individual run, spatial averaging in the cross-shore indicated that the bedform contribution was up to $15 \%$ of the transport. The maximum bedform contribution took place in the region of the breakpoint $\left(0.5<\mathrm{x} / \mathrm{x}_{\mathrm{s}}<1.5\right)$, and peaked at $\mathrm{x} / \mathrm{x}_{\mathrm{s}}=0.9$. Results from this dissipative beach experiment are in line with previous findings on intermediate beaches, steep beaches, and offshore sandbars.

\section{Acknowledgments}

Antony Thorpe contributed while funded as a UK Natural Environment Research Council (NERC) PhD student (NERC ref NE/H02543X/1). The fieldwork for this project was carried 
out alongside the project 'Dynamics of Rip Currents and Implications for Beach Safety (DRIBS)', which was part funded by NERC (NERC ref: NE/H004262/1) and the UK Royal National Lifeboat Institution (RNLI), awarded to Paul Russell and Gerd Masselink. Technical guidance and assistance in the field was gratefully received from Peter Ganderton and Megan Sheridan. Paul Russell, Gerd Masselink, Clare Earlie, Martin Austin, Tim Scott, Tim Poate, Robert McCall, Erwin Bergsma and others from the School of Marine Science and Engineering gave valued assistance in the field.

\section{References}

Aagard, T., Greenwood, B., Larsen, S.M., 2013. Total cross-shore sediment transport under shoaling waves on a steep beach. Proceedings of Coastal Dynamics (2013), Arcachon, France, 2013, pp 39-49.

Aagard, T., Hughes, M., Baldock, T., Greenwood, B., Kroon, A., Power, H., 2012. Sediment transport processes and morphodynamics on a reflective beach under storm and nonstorm conditions. Marine Geology, 326-328, 154-165 doi: 10.1016/j.margeo.2012.09.004.

Austin, M.J., Masselink, G., O'Hare, T.J., Russell, P.E., 2007. Relaxation time effects of wave ripples on tidal beaches. Geophysical Research Letters, 34, L16606, doi:10.1029/2007GL030696.

Bagnold, R.A., 1940. Beach formation by waves: some model experiments in a wave tank. Journal of the Institution of Civil Engineers, 15, $27-52$.

Bailard, J.A., 1981. An energetics total load sediment transport model for a plane sloping beach. Journal of Geophysical Research, 86, 10938-10954.

Clifton, H.E., Hunter, R.E., Phillips, R.L., 1971. Depositional structures and processes in the non-barred high energy nearshore. Journal of Sedimentary Petrology, 41 (3), 651-670.

Crawford, A.M., Hay, A.E., 2001. Linear transition ripple migration and wave orbital velocity skewness: observations. Journal of Geophysical Research, 106, C7, 1411314,128 .

Davidson, M., Huntley, D., Holman, R., George, K. 1997. The evaluation of large scale (km) intertidal beach morphology on a macrotidal beach using video images. Proceedings Coastal Dynamics 1997, Plymouth, UK. 385-394.

Doucette, J.S., 2002. Bedform migration and sediment dynamics in the nearshore of a low energy sandy beach in southwestern Australia. Journal of Coastal Research, 18, 576591.

Elgar, S., Guza, R.T., Freilich, M., 1998. Eulerian measurements of horizontal accelerations in shoaling surface gravity waves. Journal of Geophysical Research, 93, 9261-9269.

Feddersen, F., Gallagher, E.L., Guza, R.T., Elgar, S., 2003. The drag coefficient, bottom roughness, and wave breaking in the nearshore. Coastal Engineering, 48, 189-195.

Gallagher, E.L., 2003. A note on megaripples in the surfzone: evidence for their relation to steady flow dunes. Marine Geology, 193, 171-176. 
Gallagher, E.L., Elgar, S., Guza, R.T., 1998a. Obervations of sand bar evolution on a natural beach. Journal of Geophysical Research, 103, C2, 3203-3215.

Gallagher, E.L., Elgar, S., Thornton, E.B., 1998b. Megaripple migration in a natural surfzone. Nature, 394, 165-168.

Gallagher, E.L., Thornton, E.B., Stanton, T.P., 2003. Sand bed roughness in the nearshore. Journal of Geophysical Research, 108, C2, 3039, doi:10.1029/2001JC001081.

Jaffe, B.E., Sternberg, R.W., Sallenger, A.H., 1984. The role of suspended sediment in shore normal beach profile changes. Proceedings 19th International Conference on Coastal Engineering, ASCE, Houston, Texas, 1983-1996.

Hanes, D.M., Huntley, D.A., 1986. Continuous measurements of suspended sand concentration in a wave dominated nearshore environment. Continental Shelf Research, 6, 585-596.

Hay, A.E., Bowen, A.J., 1993. Spatially correlated depth changes in the nearshore zone during autumn storms. Journal of Geophysical Research, 98, 12,387-12,404.

Huntley, D.A., Amos, C.L., Williams, J.J., Humphrey, J.D., 1991. Estimating bedload transport on continental shelves by observations of ripple migration - an assessment. In Euromech 262 - Sand Transport in Rivers, Estuaries and the Sea, edited by R. Soulsby and R. Betess, A. A. Balkema, Rotterdam, 17-24.

Komar, P.D., Gaughan, M.K., 1972. Airy wave theory and breaker height prediction. Proceedings of the 13th Coastal Engineering Conference, ASCE, 405-418.

Marino-Tapia, I.J., Russell, P.E., O’Hare, T.J., Davidson, M.A., Huntley, D.A., 2007a. Crossshore sediment transport on natural beaches and its relation to sandbar migration patterns: 1. Field observations and derivation of a transport parameterization. Journal of Geophysical Research, 112, C03001, doi: 10.1029/2005JC002893.

Marino-Tapia, I.J., O’Hare, T.J., Russell, P.E., Davidson, M.A., Huntley, D.A., 2007b. Crossshore sediment transport on natural beaches and its relation to sandbar migration patterns: 2. Application of the field transport parameterization. Journal of Geophysical Research, 112, C03002, doi:10.1029/2005JC002894.

Masselink, G., Austin, M., O'Hare, T., Russell, P., 2007. Geometry and dynamics of wave ripples in the nearshore of a coarse sandy beach. Journal of Geophysical Research, 112. C1, 0022, doi:10.1029/2006JC003839.

Masselink, G., Russell, P., 2006. Flow velocities, sediment transport and morphological change in the swash zone of two contrasting beaches. Marine Geology, 227, 227-240, doi:10.1016/j.margeo.2005.11.005.

Miles, J., Butt, T., and Russell, P., 2006. Swash zone sediment dynamics: A comparison of a dissipative and an intermediate beach. Marine Geology, 231, 181-200, doi:10.1016/j.margeo.2006.06.002.

Miles, J., Thorpe, A., Russell, P., Masselink, G., 2014a. Observations of bedforms on a dissipative macrotidal beach. Ocean Dynamics, doi 10.1007/s10236-013-0677-2

Miles, J., Thorpe, A., Russell, P., Masselink, G., 2014b. Megaripple dynamics on a dissipative sandy beach. In: Green, A.N. and Cooper, J.A.G. (eds.), Proceedings 13th 
International Coastal Symposium (Durban, South Africa), Journal of Coastal Research Special Issue 70, 187-192, ISSN 0749-0208, doi: 10.2112/SI70-032.1.

Ngasuru, A.S., Hay, A.E., 2004. Cross-shore migration of lunate megaripples during Duck94. Journal of Geophysical Research, 109, C02006, doi:10,1029/2002JC001532.

Nielsen, P. 1988. Three simple models of wave sediment transport. Coastal Engineering, 12, 43-62.

O'Hara Murray, R.B., Thorne, P.D., Hodgson, D.M., 2011. Intrawave observations of sediment entrainment processes above sand ripples under irregular waves. Journal of Geophysical Research, 116, C01001.

Osborne, P.D. and Greenwood, B. 1992; Frequency dependent cross-shore suspended sediment transport 1. A non-barred shoreface. Marine Geology 106, 1-24.

Russell, P.E., 1993. Mechanisms for beach erosion during storms. Continental Shelf Research, 13, 1243-1266.

Russell, P.E., Huntley, D.A., 1999. A cross-shore transport 'shape function' for high energy beaches. Journal of Coastal Research, 15, 198-205.

Soulsby, R.L., 1997. Dynamics of Marine Sands. Thomas Telford Publications, London, UK.

Tinker, J., O’Hare, T., Masselink, G., Butt, T., Russell, P., 2009. A cross-shore suspended sediment transport shape function parameterisation for natural beaches. Continental Shelf Research, 29, 1948-1960, doi:10.1016/j.csr.2009.03.011.

Traykovski, P., Hay, A.E., Irish, J.D., Lynch, J.F., 1999. Geometry, migration, and evolution of wave orbital ripples at LEO-15. Journal of Geophysical Research, 104, 1505-1524.

Van-Rijn, L.C. 1993. Principles of sediment transport in rivers, estuaries and coastal seas. Aqua Publications, Amsterdam.

Vincent, C.E., Osborne, P.D., 1993. Bedform dimensions and migration rates under shoaling and breaking waves. Continental Shelf Research, 13, 1267-1280.

Wiberg, P.L., Harris, C.K., 1994. Ripple geometry in wave dominated environments. Journal of Geophysical Research, 104, 1505-1524.

Williams, J.J., Rose, C.P., 2001. Measured and predicted rates of sediment transport in storm conditions. Marine Geology, 179, 121-133.

Wright, L.D., Boon, J.D., Kim, S.C., List, J.H. 1991. Modes of cross-shore sediment transport on the shoreface of the Middle Atlantic Bight. Marine Geology, 96, 19-51. 